\title{
Review of microplastic sources, transport pathways and correlations with other soil stressors: a journey from agricultural sites into the environment
}

Esperanza Huerta Lwanga ${ }^{1,2^{*}}$, Nicolas Beriot ${ }^{1,3}$, Fabio Corradini ${ }^{4}$, Vera Silva ${ }^{1}$, Xiaomei Yang ${ }^{1}$, Jantiene Baartman ${ }^{1}$, Mahrooz Rezaei ${ }^{5}$, Loes van Schaik ${ }^{1}$, Michel Riksen ${ }^{1}$ and Violette Geissen ${ }^{1}$

\begin{abstract}
This paper explores different interactions and processes involved in the transport of microplastics from agricultural systems to surrounding environments. We conducted an exhaustive review of the most recent scientific papers on microplastic transport in terrestrial systems, with an emphasis on agricultural systems. In the following sections, several aspects of this problem are discussed, namely (i) direct and indirect sources of microplastics, (ii) biotic and abiotic transportation of microplastics in and from the terrestrial environment, (iii) modelling of microplastics in the terrestrial environment and (iv) facilitated chemicals and pathogens in combination with plastic particles. There is very little information available concerning microplastic transport in the terrestrial environment; therefore, more research is needed to gain a better understanding of how these processes take place. The novelty of this review lies in assessing how microplastic transport occurs from the plastisphere (cellular) to the landscape level and from agricultural systems to the surrounding areas.
\end{abstract}

Keywords: Microplastics, Agricultural soils, Direct \& indirect sources, Biotic and abiotic transport, Connections with stressors

\footnotetext{
*Correspondence: esperanza.huertalwanga@wur.nl

1 Soil Physics and Land Management Group, Wageningen University \&

Research, P.O. Box 47,6700 AA Wageningen, the Netherlands

Full list of author information is available at the end of the article
} 


\section{Graphical Abstract}

\section{PLASTIC TRAMSPORT}

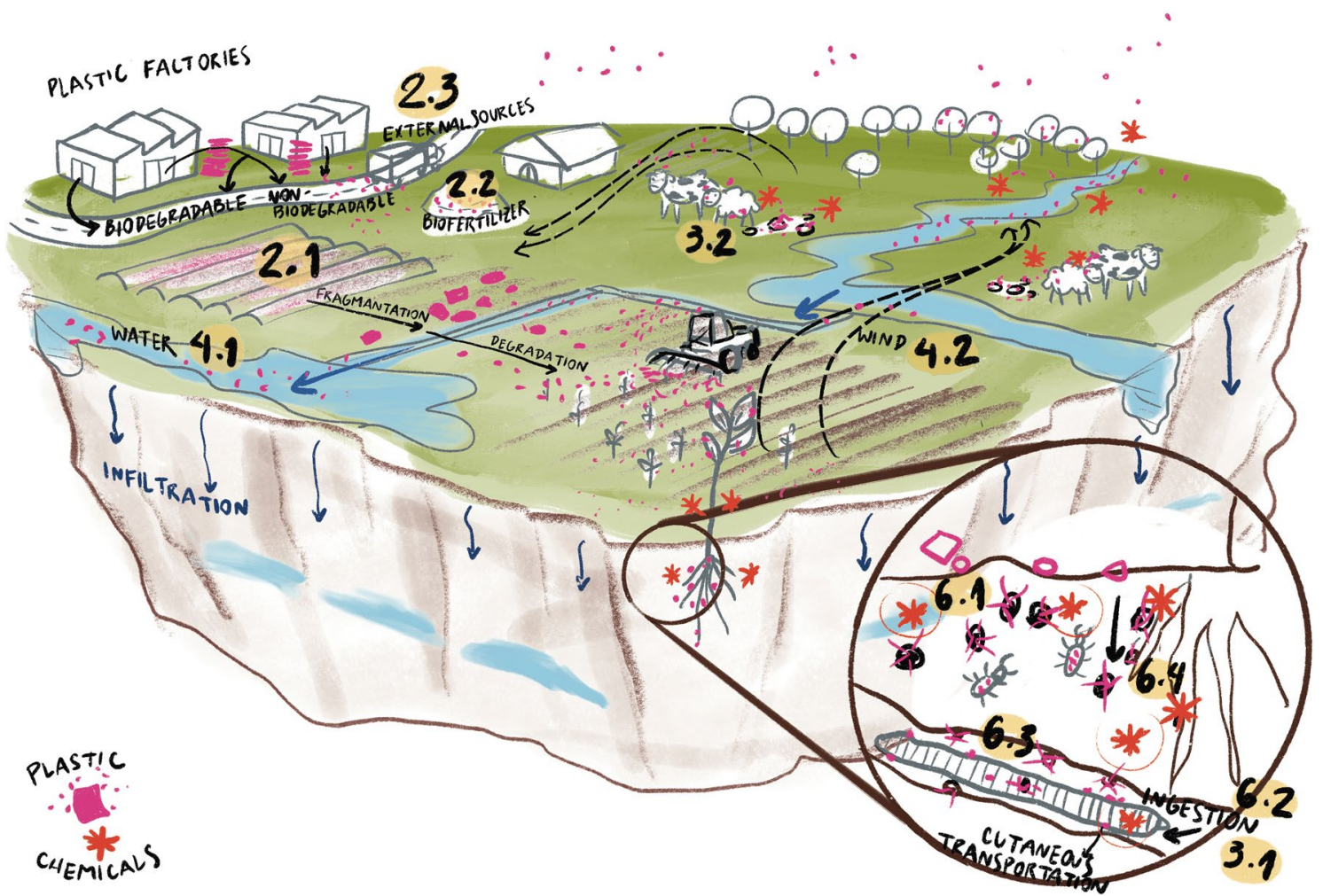

\section{Introduction}

Plastic is increasingly recognised as an massive environmental pollutant [34]. In 2019, 370 million tonnes of plastic were produced globally [118]. A production trend that has continually risen since the 1960s [153]. As a result of this increase, each year, more and more plastics end up in the environment. Due to the durability and persistence of these plastics, they remain in the environment indefinitely [113]. Rochman and Hoellein [134] explain how plastics interact from the lithosphere to the atmosphere, or from the hydrosphere to the atmosphere. Just like different chemical elements, plastic debris follows biogeochemical cycles. Plastics, according to their degradation levels are involved in a cycle involving the atmosphere, the terrestrial system (lithosphere) and the aquatic system (hydrosphere) and all of these systems are connected to each other.

Since the early 1970s, plastic pollution has been well studied in aquatic environments, mainly marine, and has only extended to terrestrial ecosystems over the last decade [155]. Researchers have revealed that plastic debris polluting the environment is not static but instead it cycles from one ecosystem to the next [134]. The plastics that cycle through the system the most are the smallest particles, such as microplastics $(<5 \mathrm{~mm}$ in diameter, [45]; [43] and nanoplastics $(1 \mu \mathrm{m}-1 \mathrm{~nm},[50]$. An estimate of mismanaged waste (including sewage sludge application) indicates that microplastics found in the terrestrial ecosystem actually add up to 4 to 23 times the amount of plastics released to the oceans [63]. In this review, we will focus on the interactions of microplastics (MP) with different soil compartments. Nanoplastics, as a product of the fragmentation and erosion of plastic particles, are still not well studied in the terrestrial environment, the main reasons involve the nanoplastics extraction methodology from the soil matrix and the detection sensibility.

$\mathrm{Xu}$ et al. [175] clearly explains that once these microplastics find their way into the soil and are "permanently" in the environment, they can accumulate, sorb contaminants or be transported through the soil matrix. There are several levels in the transportation process, some of which involve enzymes at the cellular level, breaking 
plastics into smaller pieces, or invertebrates at the organism level, exposing microplastics to ingestion processes.

The purpose of this review is to shed light on scientific gaps in our understanding of microplastic transport in the terrestrial environment. This includes the transport of off-site intentional and unintentional sources at local, regional, and global scales. We look at field and laboratory studies as well as modelling studies. In each of the following sections, we examine and discuss available literature, attempting to give new insight into theories and possible interactions that take place between microplastics, other soil pollutants and different aspects of the soil system.

Using several key words, a list of scientific papers written in English within the last 8 years was compiled.

The key words used were microplastics"transport, micr oplastics"transport"terrestrial environment.

Using the Scopus searching tool, 81 papers related to microplastics and transportation in water, soil and health were found. From these papers, $60 \%$ described the problems of microplastic distribution/transportation in Asia, $20 \%$ in Europe, $10 \%$ in America and 10\% in Australia (Fig. 1). If the word 'terrestrial' was added to the keyword search, then the number of papers decreased to 5, 3 from 2019, 1 from 2017 and 1 from 2020 (3 from Europe and 2 from Asia).

\section{Sources of microplastic pollution in agricultural soils}

In 2018, Nature published one of the first articles concerning microplastic pollution in agricultural soils. Piehl et al. [117] surveyed soil from a farmland in Middle Franconia, South-East Germany, to evaluate the incidence of microplastics in agricultural sites. The farmers used conventional agricultural practices and did not report any use of plastic or organic amendments that could potentially transport microplastics to soils. Even without the obvious use of plastic on the farm, researchers found $0.34 \pm 0.36 \mathrm{MP}$ particles per $\mathrm{kg}$ in topsoil samples. Researchers proposed establishing a background or baseline microplastic pollution level at agricultural sites, an idea that was repeated in several subsequent studies (see Table 1). The high incidence of microplastics in agricultural soils, even though there was no obvious use of plastic products or applications of organic amendment, gave rise to new scientific concerns: What happens when agricultural management practices increase pollutant pressure? How do different agricultural practices transport microplastics to soils?

In this section, we present the different pathways that microplastics can follow before they reach agricultural soils. We split the section into three subsections. In the first subsection, we list the direct sources of microplastics and how the use of plastic supplies usually results in higher microplastic pollution. The second subsection lists indirect sources related to agricultural practices that might conceal microplastics. The third exposes indirect sources related to environmental variables which is a passive way for plastics to enter soils.

\section{Direct sources: agricultural supplies made of plastic}

Agriculture relies on plastics to produce raw materials. Plastic products are found both in crop and animal production systems [105]. Plastic greenhouses, small tunnels, mulching films, protective nets, and irrigation pipes are just some of the shapes that plastics take in crop production systems. Similarly, fodder also introduces plastics into animal production systems. Twine, bale nets, and stretch films intended to preserve straw are usually made from plastic. What do the use of these plastics mean in the global context?

Of the nearly 50.7 million tonnes of plastic used in Europe in 2019, agriculture was responsible for $3.4 \%$ of it [118]. It is not a considerable share, but these plastics
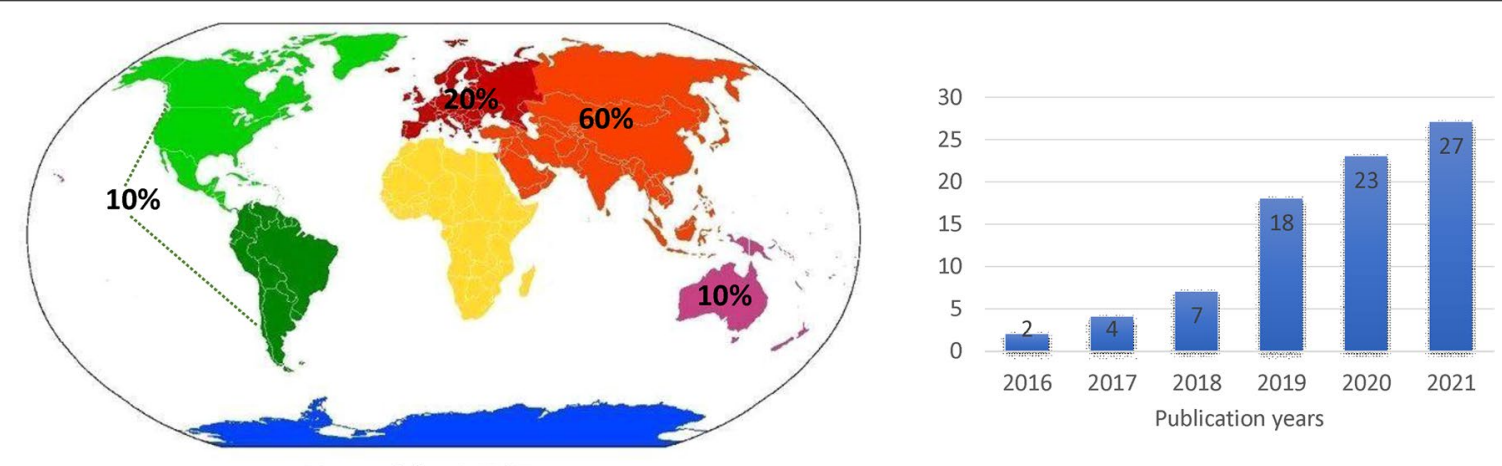

No. articles MP*Transport

Fig. 1 Microplastics and transport, number of scientific articles, and percentage of articles per continent 
Table 1 Reported concentrations of MP in soils by source

\begin{tabular}{|c|c|c|c|}
\hline Class & Author & Quantity* & $\begin{array}{l}\text { Size range } \\
\text { of analysed } \\
\text { particles }\end{array}$ \\
\hline Baseline assessment & Choi et al. [26] & 664 & \\
\hline Baseline assessment & Corradini et al. [28] & $0-306$ & \\
\hline Baseline assessment & Ding et al. [33] & $143-3410$ & \\
\hline Baseline assessment & Feng et al. [41] & $43-2$ & \\
\hline Baseline assessment & Harms et al. [56] & $0-218$ & \\
\hline Baseline assessment & Huang et al. [64] & $0.1-324$ & \\
\hline Baseline assessment & Lv et al. [99] & 10 & \\
\hline Baseline assessment & Piehl et al. [117] & 0.34 & \\
\hline Compost & van Schothorst [141] & $888 \pm 500$ & $30 \mu \mathrm{m}-2 \mathrm{~mm}$ \\
\hline Compost & Gui et al. [52] & $2400 \pm 358$ & $50 \mu \mathrm{m}-5 \mathrm{~mm}$ \\
\hline Compost & Braun et al. [21] & $7 \pm 3$ & $?-5 \mathrm{~mm}$ \\
\hline Compost & Weithmann et al. [169] & 96 & $1-5 \mathrm{~mm}$ \\
\hline Fertilizers & Katsumi et al. [76] & $6-369^{* *}$ & \\
\hline Greenhouse & Li et al. [93] & $1000-3786$ & \\
\hline Pig Manure & Yang et al. [176] & $43.8 \pm 16.2$ & \\
\hline Sheep faeces & Beriot et al. [14] & $997 \pm 971$ & $30 \mu \mathrm{m}-2 \mathrm{~mm}$ \\
\hline Plastic mulching & van Schothorst [141] & $2242 \pm 984$ & $30 \mu \mathrm{m}-2 \mathrm{~mm}$ \\
\hline Plastic mulching & Beriot et al. [14] & $2116 \pm 1024$ & $30 \mu \mathrm{m}-2 \mathrm{~mm}$ \\
\hline Plastic mulching & Huang et al. [65] & 80-308 & \\
\hline Plastic mulching & Kim et al. [81] & 215-3315 & \\
\hline Plastic mulching & Li et al. [92] & $420-1290$ & \\
\hline Plastic mulching & Meng et al. [104] & $900-2200$ & \\
\hline Plastic mulching & Yu et al. [180] & $310-5698$ & \\
\hline Plastic mulching & Zhou et al. [185] & $263-571$ & \\
\hline Sludge & Corradini et al. [29] & $1100-3500$ & \\
\hline Sludge & Crossman et al. [31] & 541 & \\
\hline Sludge & van den Berg et al. [12] & $5190 \pm 2630$ & \\
\hline Sludge & Zhang et al. [181, 183] & $87.6-545.9$ & \\
\hline Sludge & Mahon et al. [101] & $4200-15,000$ & $250-5000 \mu \mathrm{m}$ \\
\hline Sludge & Carr et al. [25] & 5000 & $?-5 \mathrm{~mm}$ \\
\hline
\end{tabular}

The table considers research articles found in Scopus database that match "MP AND soils AND agriculture" and deal with microplastic pollution of arable lands. We removed reviews, letters, conferences, and articles related to modelling and toxicology from the final list

* Quantities are expressed in MP particles per kg of dry soil. Ranges show the min and max values reported in the studies. When ranges were not reported, we took the mean value and its standard deviation. Single values without standard deviation (plus/minus sign) show that those studies only reported a single value for a treatment

${ }^{* *}$ Katsumi et al. [76] reported microplastics abundance in $\mathrm{mg} \mathrm{kg}^{-1}$

are used in close contact with soils and water. Within this share, the most used polymers were polypropylene (PP) and low-density polyethylene (LDPE), both of which are mainly used in plastic films intended for greenhouses, small tunnels, mulching films, and stretch films. Next came polyvinylchloride (PVC), the principal component of irrigation pipes and drippers. Polystyrene (PS), used in twine and nets, rounds out the list [22]. In this subsection, we will explore how each of these agricultural supplies contributes to the accumulation of MP in soils. We list these contributions according to the amount of information available.

\section{Mulching films}

Farmers use plastic mulches to increase soil temperature and water use efficiency and to decrease weed growth [39]. The downside is that farmers cannot remove the mulch completely after the growing season, leaving behind small pieces of plastic that threaten the environment. As farmers repeatedly use plastic mulches, the 
amount of plastic debris in soil increases, as does the threat of dispersion to other ecosystems [123].

Over the last few years, scientists have raised warnings about the use of plastic mulches in agriculture, arguing that they increase the incidence of microplastics in soils [166]. Most of the evidence comes from China, one of the countries, where plastic mulches are used the most. During 2015, more than 1.5 million tonnes of plastic mulch covered more than 20 million hectares of China's arable land. Liu et al. [96], one of the first studies exposing the accumulation of microplastics from plastic mulching, observed a correlation between the use of plastic mulch and the number of plastics found in soil $\left(\mathrm{R}^{2}: 0.6 p<0.05\right.$, [65]. In the years that followed the publication of Liu et al. [96], other researchers supported their observations with evidence gathered in China $[65,181,185]$ and other countries, where the use of plastic mulching is a common practice, namely, Spain [14] and the USA [49].

The reported quantity of MP found in agricultural soils due to the use of plastic mulches varies greatly between studies (Table 1). Meng et al. [104] and Beriot et al. [14] reported the highest concentrations, with values up to $2200 \mathrm{MP}$ particles per $\mathrm{kg}$ of soil. Other studies reported smaller amounts up to $80 \mathrm{MP}$ particles per $\mathrm{kg}$, an amount that is by far higher than most plastic baseline assessments.

Farmers have a choice of different plastic polymers to use as plastic mulch on their fields. Among these polymers, LDPE is the most common [74]. The use of LDPE plastic mulches has steadily risen since the 1990s, due to their low cost and their positive results on crop yields [27]. LDPE is a fully saturated polymer of hydrocarbons, which makes it highly resistant to weathering [30]. LDPE mulches need to be removed after harvest to avoid accumulation in the fields. During this process, the films tear and leave behind small LDPE debris [185]. In this regard, Liu et al. [94] baptized the process of polluting the soil with plastics through plastic mulch use as a "white revolution to white pollution".

To avoid the environmental liabilities that arise whenever farmers use LDPE plastic films on their fields, producers aim to develop new types of polymers that degrade within the soil environment. The commercial goal is to create a mulch that farmers do not need to remove every season. To date, no such mulch has been developed [125]. One industry alternative has been to speed up plastic weathering by adding oxidative compounds to the film plastic. PACs are polymers, mainly LDPE, that contain a pro-oxidant additive to enhance oxidation and photodegradation [143]. The resulting films are considered to be "oxo-degradable" or "oxo-biodegradable" (the plastic starts to depolymerize due to oxidation, [62]. In the presence of light and under aerobic conditions, PACs degrade quickly into small pieces. This small, fragmented debris is more likely to be further degraded by microorganisms [3]. However, once incorporated into the soil, the degradation process is minimized due to the absence of UVlight [62], thus causing PAC debris to accumulate [146].

The industry has also explored the use of other degradable polymers instead of LDPE. There are new mulching films on the market that can be degraded by microorganisms $[57,148]$. They are usually sold as "biodegradable" mulches (Van den [112]. Diverse polymers, which can be bio-based, petroleum-based or blends of both, can be used in biodegradable mulches [79]. The common denominator in all biodegradable mulches is their potential to degrade in situ. The European Standard (CEN norm) EN 17,033 set a requirement that to label a plastic film as biodegradable, it has to degrade by $90 \%$ within 2 years of being in the soil. To test a film's biodegradability, researchers conduct lab experiments to measure the amount of carbon dioxide produced and the decrease on mass over a certain period under controlled conditions [54]. Unfortunately, biodegradability is not only an intrinsic property of the material. In the field, biodegradability will vary depending on abiotic conditions, such as soil moisture, temperature, micro-fauna, and air permeability [107]. Consequently, some biodegradable plastic mulches do not reach their expected degradation rates in situ. For example, Ghimire et al. [49] placed commercial biodegradable plastic mulches over test fields in Washington State over a period of 4 years. The observed recovery rate was $71 \%$ after 2 years and $35 \%$ after 4 years. Ghimire et al. [49] showed that it might take more than 4 years for biodegradable plastics to reach $90 \%$ degradation in field conditions and that the decay rate of biodegradable plastic is likely to change from 1 year to another. Hydrologists have also observed the lack of robust degradability tests and the pollution that bio-based plastics produce in the environment (see [186]).

To summarize, the use of plastic mulches has become an indispensable agricultural practice in highly productive areas with sub-optimal climates. This agricultural practice increases microplastic pollution of soils, a problem that the industry cannot solve by promoting the use of existing biodegradable plastics.

\section{Plastics used to protect plants}

Plastic films and plastic-based non-woven fabrics used in greenhouses, polytunnels, shade nets, and wind barriers increase the incidence of microplastics in soil samples. However, scientists have not studied these sources of agricultural microplastics as much as they have studied plastic mulching (Table 1). Several studies have examined the contributions that plant protecting plastics have made to the levels of microplastics 
found in the environment. Other type of studies aimed at quantifying the amounts of microplastics expected to be found in soils near productive systems that use these types of plastics.

There are only a few studies that specifically target the release of microplastics from plant protecting plastics. Li et al. [93] showed that, for the same productive area, soil samples taken at farms without greenhouses had less microplastics than soil samples taken at farms with greenhouses. The authors reported a range of 1000 to $3786 \mathrm{MP}$ particles per $\mathrm{kg}$ at farms, where greenhouses were first used in the 1980s. Similarly, Kim et al. [81] reported a median of $2110 \mathrm{MPs}$ kg-1 in soil samples taken inside greenhouses, and $310 \mathrm{MPs}$ kg-1 in soil samples taken outside. The large difference Kim et al. [81] reported might come from different sources, inside greenhouses, apart from the plant protecting plastics, farmers might use plastic mulches and twine to secure growing shoots.

In a broader context, studies that report the incidence of microplastics in agricultural soils usually include or mention greenhouses. Such is the case presented by Wang et al. [168], Ding et al. [33], and Zhou et al. [185]. They all stress that the greater the use of plastic supplies, the higher the counts of microplastics in soil samples. Similarly, Dahl et al. [32] made a chrono-sequence of plastics within sediments from a bay in Spain and correlated the increase of microplastics found in the sediments with the increase of inland surface covered by greenhouses.

Other plant protecting plastics are rarely connected with microplastic pollution studies. Silva and Nanny [147] correlated high levels of microplastics in water from the Magdalena River in Colombia with the use of nonwoven plastic fabrics. They did not, however, take any soil samples. This is the only example of a scientific study that looks at plant protecting plastics, polytunnels, plastic wind barriers, or shade nets, as having a high probability of polluting soils.

\section{Silage and bale nets}

The publication of Piehl et al. [117], the first study addressing the problem of microplastics in soils at a farm scale, mentions that the use of plastics to cover grass bales and silage might pollute the fodder with MP, which, after ingestion, could reach the soil through excretion. Even though to date, there are no studies that quantify this entry path for MP to arable lands, [14] found that sheep could excrete microplastics after ingesting plastic mulch fragments, which is discussed further in this review.

\section{Twine}

Plastic twine accounted for $11 \%$ of the agricultural plastic demand in the EU in 2019 [1]. Plastic twine is mostly made of Polypropylene (PP) and used for many purposes in agriculture [51]. Twine is used to attach plants to stakes for major crops, such as tomatoes, sweet pepper and hops. It is used in banana production to bind plants to each other to prevent them from falling over [60]. Twine is also used to wrap hay bales. During harvest, the twine is cut and often haphazardly discarded in the fields, where it can end up as microplastics in the soil or in compost. Initiatives exist to encourage the use of compostable twine that can be collected along with plant residues and composted $[17,51]$. To date, no studies assess the contribution of plastic twine to soil microplastic accumulation.

\section{Coated fertilizers and pesticides}

The fertilizer industry uses plastic polymers as coating agents for slow-release fertilizers and pesticides. Once these compounds are successfully delivered, the plastic coating of the fertilizer pellet remains in soils. This is a potential source of microplastics in farmlands. To date, only one research group has gathered evidence concerning this pathway for MP to enter soils. The group reported 6-369 mg of plastics kg-1 of soil in fields, where coated fertilizers were used [76]. They also observed that the quantity of MP in estuarine waters rose during the irrigation season with $90 \%$ of the observed microplastics corresponding to the microplastics found in the coating of fertilizers [75].

\section{Plastic pipes}

Drip and sprinkler irrigation rely on plastic pipes to distribute water across a field [10]. Farmers need to replace these pipes systematically. What happens then? Do farmers leave old pipes buried and place a new line parallel to the old one or remove the old pipes with care to avoid fragmentation and plastic debris? There is no information about this pathway of microplastics into soils. Perhaps this is not a primary route for plastics to enter arable lands. Further investigation is required to identify the possible degradation or fragmentation of plastic pipes used in agriculture.

\section{Improper storage}

As explained in the previous sections, plastic can be found in huge quantities on a farm. The proper collection and storage of used plastics is additional work for farmers who do not always have the time and technical capacity to safely clean and store the used plastics. Plastic waste should be stored in a dry place, where it is protected from the wind to keep the plastic waste clean and prevent it 
from being blown away [156]. Plastic waste mismanagement in agricultural areas is a big issue which is, in part, attributed to improper storage of plastic on farms. This mismanagement causes vertebrates, such as sheep, cows, dogs, and vultures to graze and ingest plastic particles.

\section{Indirect sources: microplastics hidden in agricultural supplies \\ Sewage sludge and biosolids}

Wastewater treatment plants efficiently prevent the pollution of superficial water with MP from urban wastewater [187]. The plants trap MP from inlet water in a rich organic matrix called sludge. The sludge accumulates microplastics from urban origin, e.g., industry processes [37], domestic grey water [88], and traffic [97]. In many countries, sludge is used as a crop fertilizer and transports microplastics to agricultural fields. Corradini et al. [29] reported a range of 1100-3500 MP particles per $\mathrm{kg}$ in agricultural fields in Chile. Van der Berg (2020) repeated the experience in Spain, observing $5190 \pm 2630$ MP particles per $\mathrm{kg}$. A third study carried out in similar settings in China, reported a smaller mean range of 87.6545.9 MP particles per $\mathrm{kg}$ [183]. Along the same lines, Crossman et al. [31] observed that the more biosolids being used as crop fertilizers, the higher the accumulation of microplastics in the soil profile.

\section{Compost}

Scientists have long assumed that organic fertilizers were a source of microplastics in soil [130] but until now, very few studies have analysed the plastic content in compost. Weithmann et al. [170] identified 24 MP particles per $\mathrm{kg}$ measuring $1 \mathrm{~mm}$ to $5 \mathrm{~mm}$ in German compost from municipal organic waste and green clippings. More recently, Gui et al. [52] measured a mean of $2400 \pm 358$ MP particles per kg measuring between $50 \mu \mathrm{m}$ and $5 \mathrm{~mm}$ in compost produced in Zhejiang Province (China). Van Schothorst et al. [141] measured $1750 \pm 930 \mathrm{MP}$ particles per $\mathrm{kg}$ in the range of $30 \mu \mathrm{m}$ to $2 \mathrm{~mm}$ in Dutch compost. Regarding the most abundant polymers, Gui et al. [52] showed that PES, PP, and PE accounted for 70 to $80 \%$ of the total amount of microplastics found in compost. These records are consistent with the plastic demand of Europe [118]. Although scarce, evidence indicates that the application of compost transports microplastics to arable lands.

\section{Manure}

Manure is an unexplored way for microplastics to enter soils. After all, how do microplastics get into manure in the first place? The only study published so far was from March 2021 [176]. The authors do not provide any clue about the pathway that microplastics may follow before reaching the manure. However, they report that almost double the amount of microplastics were found in soil samples from fields fertilized with pig manure for 22 years. The authors indicate that the annual mean of microplastics in manure was $1250 \pm 640 \mathrm{MP}$ particles per $\mathrm{kg}$ of dry manure. Is this a common scenario? Further studies are urgently needed to trace potential sources of microplastics in manure.

\section{Irrigation}

Zhou et al. [185] did a comprehensive assessment of agricultural soils in Hangzhou Bay (China) and observed that irrigation water introduces microplastics to farm soils. It stands to reason that whenever superficial waterbodies are polluted with microplastics, the plastics will reach agricultural soil if farmers irrigate with water from the polluted waterbodies. This idea aligns with the global plastic cycle [133], a new concept that allows a better understanding of the problems caused by plastic pollution. Unfortunately, little is known about the quantity of microplastics that might enter a field through irrigation.

\section{Indirect sources: agriculture as a step in the plastic cycle Unauthorized dumping and oversight}

Historically, researchers have mainly focused on examining the effects of plastic contamination arising from general littering, plastic waste dumping, and inappropriate management of landfill sites [38]. The disposal of plastic at unauthorized sites has been considered one of the biggest pathways for microplastics to enter the environment [71]. It is not a pathway that is expected to directly impact agricultural soils, since unauthorized dumping most often happens in the wilderness. However, transport agents might transfer the plastics to agricultural land by one of the processes detailed in the following sections.

Baensch-Baltruschat et al. [6], wrote about microplastics originating from tire and road wear moving into adjacent places, reporting 1400-2800 tonnes per acre.

\section{Biotic microplastic transport}

\section{Plastic transportation via soil invertebrates}

Microplastic transport by soil organisms (Fig. 2) strongly depends on the size of the microplastics and the size of the organisms that are in contact with the microplastics. Small particles are moved or transported more easily than bigger particles, and small organisms will also enhance MP transport easier than bigger or more evolved organisms (i.e., we hypothesize $>$ transport in unicellular organisms than in pluricellular organisms). Different transport processes that occur in multicellular organisms, invertebrates and vertebrates are explored below. 


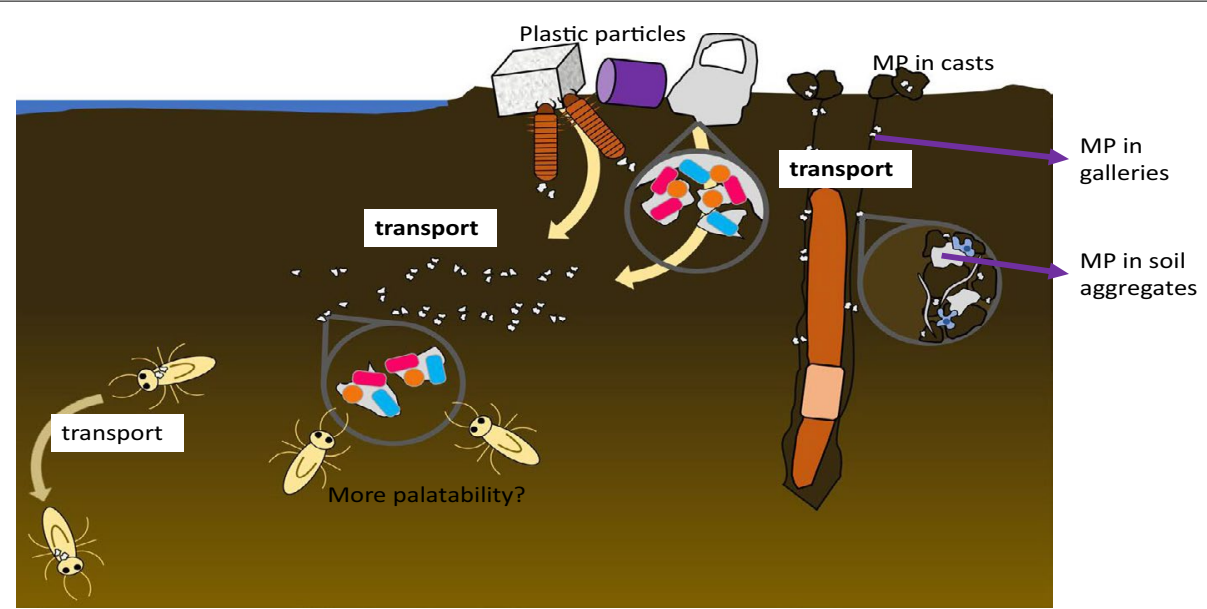

Fig. 2 MP transport by soil invertebrates taken from [58] modified

\section{Microplastic transport via electrostatic attraction, cutaneous adhesion, and soil organisms biogenic structures}

Dong et al. [35] pointed out the strong electrostatic attraction forces of small plastic particles, which promotes aggregation among particles. No information was given as to how electrostatic attraction forces exist between invertebrate tissues and plastic particles. According to Liu et al. [95], the electrostatic forces present on plastic particles increase as plastics age. More studies are needed to understand how these electrostatic forces affect transport processes involving invertebrates in the soil. It is worth noting that because of the long history of plastic use, most plastic particles in the soil have aged over time, and, therefore, might have higher electrostatic forces than pristine microplastics. When microplastics are aggregated, they are easily moved by invertebrates, such as springtails [100]. Aged microplastics are colonized by microorganisms. It has been hypothesized that these microplastics could be more palatable to soil invertebrates [58] making them more likely to be transported (Fig. 2). Scarce information is available to help us better understand how microplastic transport is affected by electrostatic attraction and soil organisms. A combination of electro-charges are involved and these interactions are dependent on soil texture, water availability and $\mathrm{pH}$.

Cutaneous transport is related to the transport of plastic particles on the surface of external invertebrate tissues. It is important to clarify that this review will not address human cutaneous-skin transport (due to the presence of plastic particles in cosmetics and personal care products). Rillig et al. [131] explained how earthworms can transport microplastics on their skin (cutaneous transportation), when exposed to high microplastic contamination. Earthworms transport plastics from hotspots into their galleries, effectively transporting plastic particles from the soil surface into deeper soil layers.

We know how earthworms such as Lumbricus terrestris drag soil and mechanically introduce plastic particles into the soil by pushing them [182] and how springtails move microplastic particles one by one [100]. It is important to emphasise that more research is required to better understand how different soil organisms introduce and transport microplastics in soil.

The most well documented form of microplastic transportation in the terrestrial environment by invertebrates is through ingestion, which has been observed in earthworms (L. terrestris and E. fetida, Huerta Lwanga et al. [66], Rodriguez-Seijo et al. [135], snails (Song et al. [149], lepidoptera and coleoptera larvae [139], nematodes [84], [91]), enchytraeids, isopodes, and mites [144]. The transportation and impact of plastic particles are dependent on a particle's size, shape and polymer type [89].

Also, in earthworms, researchers have observed how microplastics accumulate in biogenic structures, such as casts and midden ([131, 66, 67], Fig. 2). These aggregated structures need to be taken into account when considering further transport of plastic debris. More research is needed to clearly understand how this process occurs with respect to different soil types, sorts of plastics and soil management practices (i.e., tillage vs no tillage).

\section{MP transport by terrestrial vertebrates}

The transport of MP by terrestrial vertebrates has not been well documented. For aquatic environments, we have clear examples of how MP are transferred from one trophic group to another, with a greater accumulation of MP at higher trophic levels. For the terrestrial system, there is one study that looks at 
microplastic contamination and chickens found in home gardens. Chickens were allowed to roam in an area contaminated with MP. The animals ingested MP either directly from the soil or indirectly by consuming contaminated earthworms [68]. Another study focused on sheep in an agricultural setting, where plastic mulch fragments were found. The sheep ingested the plastic fragments and transported them to natural habitats, where they then defecated [14], and thus, deposited the ingested microplastics.

Studies of other ungulates, such as deer in nature reserves, have reported how these animals are contaminated with MP [126] and transport them in their faeces. Another vulnerable group are birds. Terrestrial birds living in or near cities ingest plastic particles as they forage for food and also use plastic particles as decorations in the construction of their nests [145]. Interestingly, the presence of nest decorations are indicators of environmental quality [145]. Carrion-eating birds such as vultures have transported microplastics from rubbish dumps to their nesting sites [8]. However, there are no studies looking at the transport of MP from agricultural areas to terrestrial bird nests, and therefore, more studies are required.

\section{Flux of MP transport by soil organisms}

In this section, biotic transportation flux is defined as the time required for an organism to ingest, assimilate, and excrete microplastic particles. The biotic transportation flux is dependent on the type, size and shape of the plastic particles: smaller particles will be more rapidly transported by smaller organisms. Invertebrates will be faster or will have higher transport flux rates than vertebrates (Fig. 3). In fact, there are several factors that play an important role in the biotic transportation flux of microplastics, such as the bioaccumulation or non-bioaccumulation of plastic particles in organisms, the time of exposure, the inherent defence mechanisms that each organism may have, the time that these plastic particles remain in the body of the organism, etc. So far, there has been no study that incorporates all of these influencing factors in examining the relationship between the transport and accumulation of plastic particles in invertebrates or vertebrates. Take oil-based microplastics as an example for one of these studies. If we expect that oilbased MP will not accumulate in organisms as easily as biobased MP, we can expect that oil-based plastics would be transported more. There are, as of yet, no studies that analyse this hypothesis.

\section{Abiotic transport of microplastics}

Plastics have a long residence time in soils [150, 152]; therefore, it is highly likely that soils act as long-term sink for MP debris [63]. The transport of plastic on land is poorly understood and site-specific work is required to quantify the magnitude and timing of plastic redistribution on land $[63,90]$. The processes, i.e., redistribution in the soil profile and transport to groundwater as well as wind and/or water erosion, runoff [109] and the main drivers (e.g., topography, land use, climate, vegetation, particle shape and size $[63,90]$ are poorly understood. In this review, we examine the transport of MP by wind and water, focussing on the agricultural site scale.

\section{MP Transport by water in the soil profile}

Apart from the active or passive transport of MP in soils by soil organisms, MP can be transported down to deeper layers in a soil profile with percolating water. Leaching of

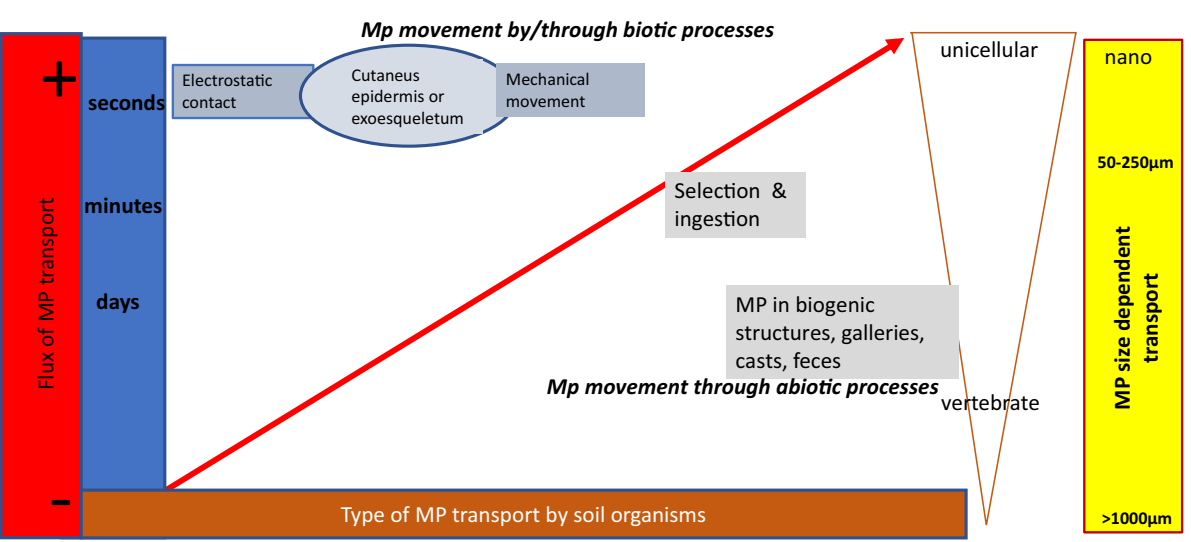

Fig. 3 Hypothetical biotic flux of MP transport from invertebrates to vertebrates. The type of plastic may imply accumulation or rejection. We hypothesize that oil-based microplastics will be more easily transported than bio-based microplastics. The red line indicates the direction of the MP flux transport increment 
MP through the soil matrix is limited and depending on the size and shape of MP as well by the matrix pore size distribution. MP particles can be transported faster and deeper into the soil profile through preferential flow in macropores, such as cracks or biopores $[178,188]$. The depth to which the MP particles can then be transported is likely to depend on the depth distribution and connectivity of the macropore network. Where the macropores end the MP particles will likely again be limited in their further downward leaching by the pore size distribution of the matrix.

MP can affect soils through physico-chemical changes on soil texture and structure [122], which is consequential for water cycling and ecosystem functioning in terrestrial systems and diverse plant-soil feedbacks [13, 152].

While the water can be a means of transport for MP, at the same time the MP particles may affect the soils through physico-chemical changes, on soil structure and texture and thereby influence the processes of water flow [122] and ensuing MP transport. On the one hand when MP become embedded inside soil aggregates [131], their transport will be restricted. On the other hand the soil structure might lead to increased preferential flow. For clayey and silty loam soils Zhang et al. [184] and Wang et al. [165] found that MP fibers increased the formation of larger aggregates, with large pores and little amount of small pores, without altering soil bulk density or the saturated conductivity. In line with this, Jiang et al. [72] found that the presence of residual plastics film fragments resulted in a lower bulk density and higher porosity, increasing consequently the heterogeneity in the infiltration pattern in field soils. Wan et al. [164] found that MP in soil increased the evaporation rate and thereby also increased the shrinkage of clay soils. This may lead to strong water shortage and more preferential flow through cracks, potentially resulting in a large vertical transport of MP to deeper layers. Seemingly contrasting to this De Souza Machado et al. [152, 151] found an increasing water holding capacity with increasing concentrations of polyester fibres, and decreasing water stable aggregates; however, they found no significant changes in soil hydraulic conductivity.

In line with Wan et al. [164], O'Connor et al. [111] found that it is not the volume of water which passes through a sandy soil column in laboratory which determines the MP transport in depth, but rather the number of drying and wetting cycles. Although a sandy soil will not experience shrinking like a clay soil, the importance of drying and wetting cycles points out that hydrophobicity of the MP and matrix with the resulting preferential flow might be a trigger for the increased transport. Dong et al. [36] studied the effect of different chemical factors on the soil solution, such as electrolytes, $\mathrm{pH}$ and humic acids, on MP transport. They concluded that the transport was determined more by the size and shape of the MP than by the chemical factors.

In agreement with the above, according to Blasing and Amelung [18] most MP (especially $>1 \mu \mathrm{m}$ ) are filtered out in soils and can remain in soils for decades. However, as colloidal transport can take place along macropores [11], with first-flush and wet and dry cycles as found by O'Connor et al. [111] being important triggers for deeper transport. MP transport to (shallow) groundwater might occur in case macropores reach the groundwater level. MP fibers have been found in karst systems [115], which are known to be vulnerable for pollution, due to their well-connected large pore/fissure systems. As karst systems constitute about $25 \%$ of global drinking water sources, this is a matter of concern [115]. However, to our knowledge, no MP have been found in other groudwater sources, although there are several calls to monitor groundwater for MP contamination [69, 82, 127]. Mintenig et al. [106], and Su et al. [154] found very low contamination of drinking water coming from groundwater and concluded that this contamination occurred during transport.

Although transport of MP to deeper layers is probably limited in most soils and degradation of buried MP in soils is known to be slow [87], it is important to keep in mind that after degradation to nanoplastics the transport of the particles to deeper layers and groundwater will likely increase, as nanoparticles might leach through the soil matrix more easily.

The conclusion by Rillig et al. [131], that dedicated experiments in the lab, and eventually in the field, are urgently needed to estimate rates of MP particles movement and to disentangle the relative roles of the various factors potentially influencing that movement, still holds.

\section{Transport by overland flow and erosion}

Transport of plastics is likely to take place over the soil surface due to runoff and water erosion (for wind erosion see Sect. 4.3 below), following the hydrological and sediment transport pathways determined by topography, surface morphology, land use, etc. [173]. Runoff is generated via two main processes: (i) Hortonian, or infiltration excess overland flow, where the rainfall intensity exceeds the infiltration capacity of the soil and (2) saturation excess overland flow, where the soil is saturated with water and cannot store anymore rainfall. Plastics may have an indirect effect on runoff production and erosion by changing the soil properties that affect runoff generation and erodibility, such as infiltration capacity, water storage capacity, hydrophobicity, and aggregate stability, as explained in 4.1. 
The increasing water holding capacity found by De Souza Machado et al. [24-151] with increasing concentrations of polyester fibres, and decreasing water stable aggregates, might affect erodibility. De Souza Machado et al. $[150,152]$ found no significant changes in soil hydraulic conductivity, an important factor for runoff generation and erosion. Qi et al. [122, 123] found an increase in $\mathrm{pH}$ and a decrease in $\mathrm{EC}$ in pot experiments. However, most studies were conducted using controlled pot experiments, effects in field situations remain under-studied.

The results of the first investigations on the influence of microplastics on soil hydrological processes indicate that more extensive studies and more field studies, in particular, are needed to quantify the effect of MP on soil properties. Researchers also need to investigate how these changes in soil properties, in turn, lead to changes in runoff generation and transport of MP with runoff water and erosion. In case runoff is generated, the transport of microplastics with the runoff water is likely to depend on the degree to which the MP are captured in aggregates, the stability of the aggregates, and the density and hydrophobicity of the microplastic particles.

The transport of plastic on land, however, is still poorly understood and site-specific work is required to quantify the magnitude and timing of plastic redistribution on land and transport from the terrestrial system to surface waters $[63,90]$. We found only one very recent publication on soil erosion as a transport pathway of MP from agricultural soils: Rehm et al. [128] carried out a rainfall simulation experiment in Southern Germany and concluded that arable land, susceptible to soil erosion, could be a substantial source of MP for downstream aquatic ecosystems. Windsor et al. [173] used a hydrological catchment as a well-defined unit of analysis for plastic pollution review, but concluded that sources, fluxes and sinks in catchments are poorly quantified. Thus, although the pathway for the transport of microplastics with runoff and soil erosion has been often mentioned (e.g., [63, $114,173]$, actual empirical evidence supporting this phenomenon is still lacking $[18,173]$. While Nizzetto et al. $[109,110]$ presented a hypothetical modelling study on the catchment-wide transport of plastics with sediment (see Sect. 5 below), studies directly investigating this transport, be they laboratory (e.g., rainfall simulation or flume studies) or field studies, are very scarce (but see [128]. Consequently, there is a very clear gap in research on the processes, magnitude, timing and drivers of plastic transport via runoff and erosion on land.

When considering a larger area than agricultural fields or landscapes, indirect evidence of microplastic transport by erosion comes from microplastics found in sedimentary environments, such as channel beds and alluvial fans as well as lake shores and beach sediments [114]. However, researchers mainly focus on relatively large catchments and/or stretches of rivers in their studies, and pollution sources are often urban areas (e.g., [40, $63,83,134]$. Studies rarely look at the contribution of agricultural catchments. Lutz et al. [98] investigated the transport of MP in sediments from stormwater drainage systems in Australia, where fewer MP were found in an agricultural catchment as compared to an urban catchment. Liu et al., [97] found a large variation in MP occurrence in stormwater retention ponds but focused on ponds draining residential areas and highways.

\section{Wind erosion transport}

Light polymers could be transported by wind erosion across soil systems [63] and eventually toward streams and rivers. Especially in areas prone to wind erosion, plastic particles can be easily picked up by the wind and find their way into the atmosphere, affecting the quality of the air we breathe. The increased aridity that will be enhanced by climate change in many regions of the planet will make soils more vulnerable to wind erosion. Since a significant part of the affected wind-prone areas are used for agricultural purposes and agricultural soils can act as long-term sinks for microplastics [130], wind transport of microplastics could result in environmental and human exposure occurring far beyond the original source. Importantly, aeolian transport of microplastics is likely to lead to the widest dispersal as it is the least limited by environmental boundaries, influenced mainly by the directions of air movement rather than the unidirectional water flows that are generally present on land and within waterbodies.

Zylstra [189] revealed the role of wind action in spreading light macroplastic particles to other terrestrial locations. He quantified wind-dispersed trash and plastic debris in a protected desert area in Southern Arizona which could pose a threat to those arid environments. He indicated that trash densities were largely independent of road proximity, suggesting that wind could carry plastic bags and balloons $>2 \mathrm{~km}$ into remote areas.

Knowledge of the transport of MP with soil wind erosion is sparce because of inadequate research. Rezaei et al. [129] first revealed the key role of wind erosion in the spread of MP in terrestrial environments using a portable wind tunnel in the field. They reported that wind-eroded sediments from both agricultural and natural lands were enriched with microplastics. Bullard et al. [23] went one step further and explored the extent to which MP were preferentially transported by wind erosion. They conducted laboratory wind tunnel experiments and concluded that MP shape was an important factor in such transportation. They also reported that 
the inclusion of MP did not significantly affect the wind erosion threshold. This is a principal factor for investigating the effect of MP on soil erodibility. Interestingly, their results showed that the enrichment ratios of plastic particles did not demonstrate any significant or systematic variability with distance downwind (over $2 \mathrm{~m}$ ) which suggests once entrained into the air flow, particles may be transported away from their source.

Apart from research on the wind erosion transport of MP, there are several studies on the presence of MP in the air. However, most of the studies on airborne MP are mostly conducted within cities or indoors, where there are other sources of MP rather than agricultural soils, such as synthetic clothing, anthropogenic activities, and fragmentation of large plastics. Therefore, the contribution of agricultural soils to MP air pollution is largely unknown. Recently, Peñalver et al. [116], quantified polystyrene microplastics in the atmosphere near an agricultural area (36 ng m-3). Better quantification and understanding are still required, since there is a high chance of adsorption of other pollutants (e.g., pesticides) from agricultural soils to MP [9] [2, 61]. There is a major knowledge gap regarding the concentration and transport of MP in different fractions of particulate matter (especially PM10 and PM2.5). These particles are tiny and can be easily inhaled, posing a severe threat to human health depending on the chemical composition of the particles and the susceptibility of each individual $[80,119]$.

\section{Modelling microplastic transport in terrestrial environments}

Various types of models exist that are applied to the analysis of microplastics, including (i) process-based transport models that aim to simulate MP transport in/ through the terrestrial environment (e.g., [85], Nizetto et al., 2016a), (ii) models to map and analyse the spatial distribution of MP in the soil/landscape and understand microplastic transport (e.g., [78, 181, 183] and (iii) conceptual models that provide a methodological basis for further investigation and risk assessments that summarize and synthesize existing (and missing) research (e.g., 86, [162].

Process-based modelling of plastic transport has been done for riverine systems (e.g., [85] [16] and for transport from rivers to oceans (e.g., [172]. The first and only process-based MP model, as far as we know, that assessed catchment-scale plastic transport with sediment is INCA-Contaminants $[109,110]$. This model aims to simulate the mechanisms of plastic storage, entrainment and deposition in soils and streams as a function of hydrological and pedological factors. However, due to the lack of empirical data on plastic emissions and concentrations in soils and streams
$[109,110]$ could only present the model as a theoretical assessment. They found that size, in contrast to density, appears to be a more sensitive parameter and that, depending on soil characteristics and precipitation patterns in sub-catchments, $16-38 \%$ of plastics added to the soil with sludge were predicted to remain in the soil. Unice et al. $[159,160]$ assessed the fate of tire and road wear particles (TRWP) in the Seine basin using an integrated geospatial microplastic transport model. Based on these (preliminary) modelling results and attempts, conclusions and recommendations by various authors (e.g., $[20,109,110,174])$ can be summarized as (i) it is challenging to cope with the lack of data on the quality and quantity of microplastic input into the environment-with the related recommendations for dedicated experiments and monitoring studies, (ii) there is a lack of understanding about the transport processes of microplastics in terrestrial ecosystems and the related need for mathematical equations for MP transport-different than existing transport equations for sediment transport, as underlined by Rehm et al. [128] and (iii) there is a lack of knowledge concerning the behaviour of MP microplastics in different environmental compartments, such as accumulation rate, fragmentation rate and (bio)degradation rate and their influence on the further fate of the MP. Brandes et al. [19] also concluded in their synthesis report with seven different models of microplastic transport from agricultural fields to rivers in Germany.

A second application of modelling involves studies that aim to predict and explain the MP transport in(to) the environment based on spatial mapping with statistical models and proxy data. For example, Kawecki and Nowack [77, 78] mapped the emissions of macro- and microplastics for seven polymers in Switzerland, based on a complete analysis of the flows from production and use to the end-of-life using probabilistic material flow analysis (PMFA), including a systematic uncertainty analysis and propagation using Monte Carlo simulations. For this type of modelling, a transfer coefficient (C) matrix describes all the flows from one process to another. Input vectors quantify all the external inputs to the defined system [77]. Using this analysis, Kawecki and Nowack [77] concluded that littering is the leading emission pathway and, given that mass flows of MPs into soils are predicted to be 40 times larger than those into water, more attention should be placed on this compartment. In a follow-up study, Kawecki and Nowack [78] produced a high-resolution spatial map of macro- and microplastic emissions for soil, freshwater and air using geographical data sets on land use, traffic, population density, WWTPs and sewer overflows as proxies. Zhang et al. $[181,183]$ used spatial distribution mapping of low 
density microplastics and macroplastics to infer the main transport mechanisms of microplastics on the farmland scale.

A third way of using models in MP-related analyses is to use conceptual models to summarize and synthesize existing information and identify knowledge gaps. Waldslaeger et al. [162, 163] applied the Source-Pathway-Receptor (SPR) model to compile current knowledge on plastic pollution. It provides a system model for the evaluation of MPs in different environments with regards to the individual components and their interrelationships, combining the transport pathways with the receptors to assess consequences of MP in the environments [163]. They first identified and defined the sources (generation and production sites) and entry paths, then described the transport pathways between and within several compartments (e.g., aquatic, terrestrial, aerial), as well as concentrations observed in these compartments, and finally, receptors were defined as all media that were impacted by the pollutant [165]. The authors concluded that a model such as SPR can be further elaborated and used to implement controls to reduce MP pollution most effectively. Koutnik et al. [86] studied the spatial distribution of microplastics and showed that the microplastic concentrations were high in urban soil/ water as well as on remote lying glaciers, which shows that wind-driven transport is also significant. They subsequently derived theoretical models to predict microplastic transport.

\section{The impact of other stressors in MP transport}

MP behave differently when combined with other stressors (i.e., chemicals and pathogens) that are also commonly present in the soil from the plastisphere $[4,131]$. To understand the interactions that take place among MP and other stressors, it is important to first understand certain phenomena, such as sorption and desorption.

Sorption is, by definition, the process of transfer of a substance from a fluid phase such as air or water, to a solid phase such as plastic, soil organic matter or organisms' tissues [42]. Desorption is the reverse process. The term "sorption", covering both adsorption and absorption processes, can be seen as a balance between the affinity of a chemical with the mobile phase and the available solid phases. Different chemicals have been reported to adsorb to MP, some at very high levels [102]. Considering the transport of MP previously presented, MP-facilitated transport of toxic chemicals to other areas and compartments as well as changes in the accumulation and toxicity of the transported chemical substances must be considered. This scenario becomes even more complex when MP co-exist with multiple chemicals and with microbial adipate-co-terephthalate (PBAT films that were incubated in an agricultural soil in the laboratory
(6 weeks,temperature of $25{ }^{\circ} \mathrm{C}$, from Sander [140]. The images illustrate colonization of PBAT films by both fungi and unicellular organisms. Images in panels a) and c) were taken at different spots on the PBAT film surface. Panels b) and d) show magnifications of areas highlighted inpanels a) and c). Pathogens (fungi and bacteria), or when MP additives desorb and act as contaminants [24, 59]. Therefore, it is crucial to address the factors affecting chemical and microbial associations with plastics and the implications of these associations.

Sorption of contaminants onto plastic depends on the properties of the plastic and the contaminant as well as the surrounding environment (Fig. 4). One of the most important factors in MP-contaminant/pathogen sorption processes relate to the contact surface of plastics (debris size). The contact surface depends on the size of the plastic debris and on its molecular chain arrangement (polymer crystallinity). The molecular chain arrangement varies for different polymer types but can also vary for the same polymer, depending on the production process [136]. The molecular chain arrangement can create porosity in the polymer structure. For example, Seidensticker et al. [142] measured a pore size of about 195 Angstrom for Polystyrene, while Polyethylene was observed to be non-porous. Higher porosity means a greater contact area with the contaminant and, therefore, more sorption. In addition, the type of polymer influences the type of interaction with the contaminants, i.e., potential hydrogen bonds, covalent bounds, Van der Waals forces and electrostatic interactions. The aging of plastics also affects the chemical structure of the polymer and, therefore, the sorption processes. For example, Weng et al. [171] showed that aged polybutylene adipate terephthalate was able to form hydrogen bonds with organic chemicals [171]. A second example is the higher concentrations of heavy metals (As, $\mathrm{Ti}, \mathrm{Ni}$ and $\mathrm{Cd}$ ) in environmentally weathered plastic debris as compared to new plastics, probably because of increased levels of oxidation in the environmental plastic [121].

The chemical structure of the contaminants also plays a determinant role in the sorption process. Hydrophobicity, for instance, can be seen as the main factor in explaining the sorption of organic contaminants to plastic [5]. Hydrophobicity is often measured with the octanol-water partition coefficient $(\log \mathrm{P})$, and contaminants with higher $\log \mathrm{P}$ are, in general, more susceptible to sorption $[5,53]$. However, for organic contaminants, $\log \mathrm{P}$ is not enough to predict the sorption on plastic [15]. For example, the solubility in the liquid phase also plays a major role (Guo et al. 2000), which will be influenced by the affinity of the contaminant with other dissolved substances [46]. For metals, the potential to form a complex with the plastic reactive groups, such as hydroxyls, 


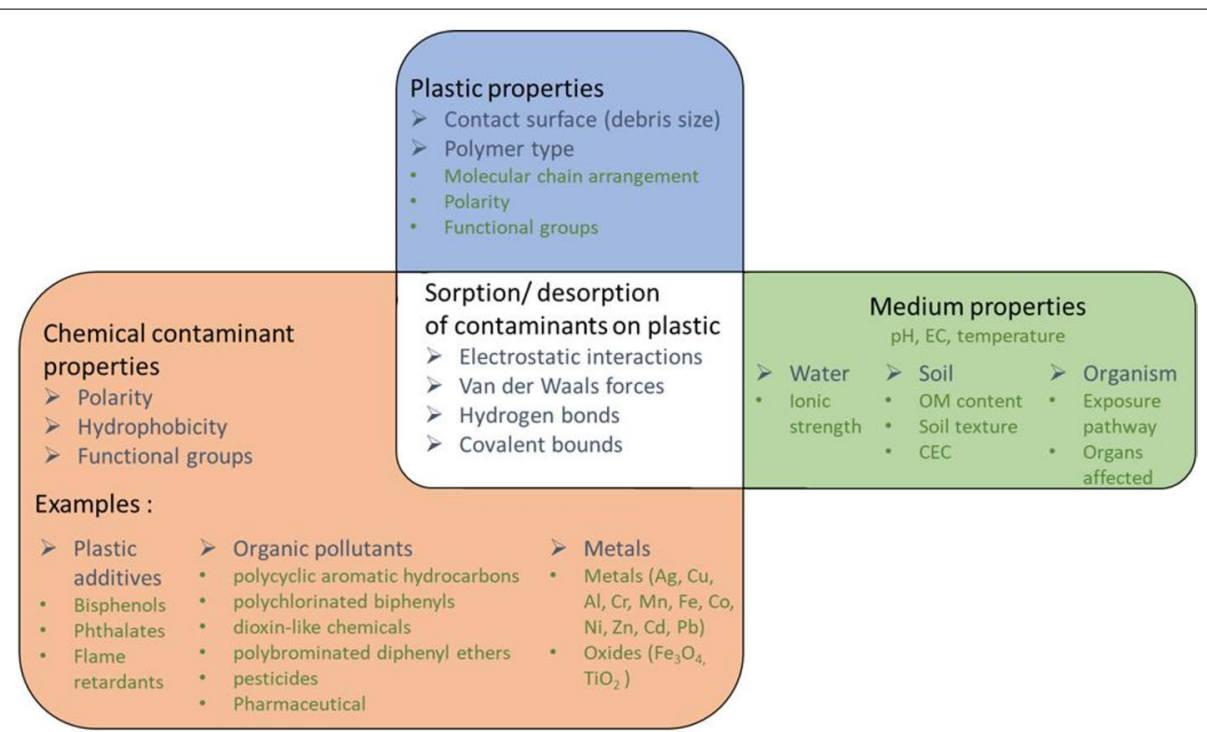

Fig. 4 Summary of the main plastic, chemical pollutants and medium properties involved in sorption processes. EC electric conductivity, OM Organic Matter content, CEC cation exchange capacity

amines, thiols, and carboxylic acids, appears to be a determinant factor (Abdolahpur [108, 132].

Finally, all the sorption processes are inevitably influenced by the properties of the medium, especially $\mathrm{pH}$ and salinity for water [102]. Electrical conductivity and ionic strength can play a role as well $[42,142]$. Medium characteristics also influence the sorption to other phases, such as the soil organic matter, the soil particles or the organisms' tissues [167, 178]. Sorption to the medium will compete with sorption to the liquid phase or the plastic. For example, in soil, an increased soil organic carbon content will likely increase the sorption of organic contaminants to the soil [47], while dissolved organic matter and dissolved humic acids will likely increase the solubility of the same contaminants in the soil water solution [138]. The complexity of the interactions is highlighted by Gaonkar et al. [46] who studied the impact of soil organic amendments on sorption of organophosphate pesticides. No clear correlation between increases in soil organic carbon and pesticide sorption could be established but the study confirmed that dissolved organic matter and dissolved humic acids caused greater solubilization of chlorpyrifos.

In addition to the chemical contaminants previously considered, microorganisms can also be found on the surface of plastic [4, 102, 137]. Microorganisms can use the plastic debris as a surface to colonise and/or as a source of nutrients (e.g., plastic degrading bacteria; [161]. The colonisation of plastic can result in biofilms, as aggregates of cells within a matrix of extracellular polymeric substances. The plastic properties, such as the type of polymers and the porosity are crucial for the development of biofilms [161]. Some adsorbed microorganisms produce enzymes (e.g., hydrolases) as EPS that can degrade the polymer [140]. This is the case for designed biodegradable plastics which are more easily degraded by the microorganisms. Microorganisms attached to plastic can also be pathogens for other organisms [4]. When MP degradation takes place, more MP transport occurs by water through preferential flow [179].

\section{Transport of pollutants attached to MP from the source to other environments/ organisms}

When attached to MP, chemical contaminants and pathogens can be transported with MP and contaminate other environments (i.e., effect of polystyrene and chlorpyriphos on Oncorhynchus mykiss, or the effect of polyethylene and abamectin on zebrafish, $[55,73])$. For soil, there are several studies on the transport of contaminants associated with MP, most of them on simulations under porous media conditions [70]. The transport of the herbicide glyphosate was higher in soil with additions of MP, for instance [177]. However, transport seems to be compound specific. Hüffer et al. [70] observed that the presence of PE MP in soil increased the mobility of atrazine and 4-(2,4-dichlorophenoxy) butyric acid, while Liu et al. [96] reported that nano-plastic significantly enhanced the transport of pyrene and 2,2,4,4'-tetrabromodiphenyl ether compounds but saw no effect on the transport of bisphenol A, bisphenol F, and 4-nonylphenol. However, due to soil properties, such as porosity, organic matter, humic acid and aggregate structure, 
contaminant transport and dispersion also depends on the adsorption capacity of the contaminant in soil or on the surface of micro/nano-plastics [7]. Furthermore, the aging effects of plastic particles and contaminant properties, such as degradation, would also affect combined $\mathrm{MP}-$ contaminant transport capacity in or through a soil profile, considering different soil textures and plastic types. Unfortunately, the detailed transport mechanisms of contaminants combined with micro/nano-plastics are still insufficiently understood, especially the possibility of combined substance transport to plants [92], as well as MP-microbe interactions [168]. There is evidence that plastic debris carries pathogens $[103,157]$. Therefore, MP particles might facilitate contaminant transport in environmental systems, but further studies are needed.

\section{Perspectives}

Even though this review does not discuss the risk assessment of MP transport on human or environmental health, we know that soil diversity decreases with microplastic exposure [150, 152], that plants are affected [124] by the type and size of microplastics [48], and overall, that MP move horizontally and vertically from one site to another. Prata et al. [120], clearly reported how humans are infested by microplastics and nanoplastics through ingestion (by water or food contaminated with MP), direct skin contact (via personal hygiene products that carry plastic particles), and through inhalation (when micro- or nanoplastics are carried by wind and then inhaled). Studies by [158] and [44] indicate how derivatives of plastic particles, such as phthalates, produce endocrine disruptions in men and women. Therefore, more investigations are needed in relation to the transport of MP in the terrestrial system, for environmental and human sake.

\section{Conclusions}

MP transport in agricultural systems drives the need to understand the interconnections that occur at different scale levels, involving time of exposure, land management [compost or mulch use (direct sources)], interactions with agrochemicals, such as pesticides (other stressors), and soil characteristics as well as the size, shape and type of plastic (bio or oil based).

Biotic and abiotic transport occur after plastic is fragmented in the soil. For instance, a farmer might trigger the fragmentation of plastic by ploughing the soil, leaving the plastic pieces exposed to UV rays, wind and water which causes them to fragment into smaller pieces. MP transport occurs as vertebrates, together with macro-, meso- and micro-invertebrates, ingest and transport the MP. Anecic invertebrates move MP into deeper soil layers as they move inside their biogenic structures, or middens. MP are carried by water and preferential flow into the groundwater and beyond. Imagine, MP could be ingested by earthworms or snails, which could then be consumed by chickens, sheep or deer, which could ultimately be consumed by humans. Some microplastics take a different route and spread abiotically through wind erosion. If there is a strong soil affectation, these plastic particles can move long distances, from the lithosphere into the atmosphere and to the hydrosphere. There are models that can predict MP movement from agricultural sites to fresh water. However, we still need to understand how all these interactions take place under different agricultural conditions and how different soil characteristics and kinds of plastics affect the movement of plastic particles through the environment.

\section{Abbreviations}

MP: Microplastics; PF: Preferential flow; PP: Polypropylene; LDPE: Low density polyethylene; PE: Polyethylene; PES: Polyester; PVC: Polyvinyl chloride; PS: Polystyrene; PACs: Pro-oxidant additive containing plastics; WWTPs: Wastewater

Treatment Plants.

\section{Acknowledgements}

We acknowledge Robin Palmer for the English edition and Natasha Sena for the graphical abstract draft design.

\section{Authors' contributions}

EHL conceived manuscript \& graphical abstract ideas, sections writing, edited drafts and references. NB sections writing, edited document, developed graphical abstract. FB sections writing \& document edition. VS sections writing \& document edition. XY sections writing \& document edition. JB sections writing \& document edition. LVS sections writing, document and references edition. MR wrote section \& document edition. MR wrote section. VG document edition. All authors discussed the graphical abstract and contributed to the final manuscript.

Funding

There was not funding for elaborating this review.

Availability of data and materials

Not applicable to the review.

\section{Declarations}

Ethics approval and consent to participate Not applicable.

\section{Consent for publication}

Not applicable.

Competing interests

There are not conflicts of interest.

\section{Author details}

${ }^{1}$ Soil Physics and Land Management Group, Wageningen University \& Research, P.O. Box 47, 6700 AA Wageningen, the Netherlands. ${ }^{2}$ Agroecología, El Colegio de La Frontera Sur, Unidad Campeche, Campeche, Mexico. ${ }^{3}$ Sustainable Use, Management and Reclamation of Soil and Water Research Group, Universidad Politécnica de Cartagena, Paseo Alfonso XIII, 48, 30203 Cartagena, Spain. ${ }^{4}$ Instituto de Investigaciones Agropecuarias, INIA La Platina, Casilla 439, Correo 3, Santiago, Chile. ${ }^{5}$ Meteorology and Air Quality Group, Wageningen University \& Research, P.O. Box 47, 6700 AA Wageningen, The Netherlands. 
Received: 17 August 2021 Accepted: 2 December 2021

Published online: 12 February 2022

\section{References}

1. APE-Europe, 'Plasticulture in Europe-Statistics'. https://apeeurope.eu/ statistics/. Accessed March 2021

2. S Abbasi F Moore B Keshavarzi PK Hopke R Naidu MM Rahman P Oleszczuk J Karimi 2020 PET-microplastics as a vector for heavy metals in a simulated plant rhizosphere zone Sci Total Environ https://doi.org/ 10.1016/j.scitotenv.2020.140984

3. T Ahmed M Shahid F Azeem I Rasul A Ali Shah M Noman A Hameed N Manzoor I Manzoor S Muhammad 2018 Biodegradation of plastics: current scenario and future prospects for environmental safety Environ Sci Pollut https://doi.org/10.1007/s11356-018-1234-9

4. LA Amaral-Zettler ER Zettler TJ Mincer 2020 Ecology of the plastisphere Nature Rev Microbiol https://doi.org/10.1038/s41579-019-0308-0

5. Aslam S, Garnier P, Rumpel C, Parent SE, Benoit P. Adsorption and desorption behavior of selected pesticides as influenced by decomposition of maize mulch. Chemosphere. 2013;91(11):1447-55. https://doi. org/10.1016/j.chemosphere.2012.12.005

6. B Baensch-Baltruschat B Kocher C Kochleus F Stock G Reifferscheid 2021 Tyre and road wear particles-a calculation of generation, transport and release to water and soil with special regard to German roads Sci Total Environ https://doi.org/10.1016/j.scitotenv.2020.141939

7. Bakir A, Rowland SJ, Thompson RC. Transport of persistent organic pollutants by microplastics in estuarine conditions. Estuar Coast Shelf Sci. 2014;140:14-21. https://doi.org/10.1016/j.ecss.2014.01.004

8. F Ballejo P Plaza KL Speziale AP Lambertucci SA Lambertucci 2021 Plastic ingestion and dispersion by vultures may produce plastic islands in natural areas Sci Total Environ https://doi.org/10.1016/j.scitotenv.2020. 142421

9. B Beckingham U Ghosh 2017 Differential bioavailability of polychlorinated biphenyls associated with environmental particles: microplastic in comparison to wood, coal and biochar Environ Pollut https://doi.org/ 10.1016/j.envpol.2016.09.033

10. RW Beieler 2013 Pipelines for water conveyance and drainage American Society of Civil Engineers Virginia

11. K Benhabib MO Simonnot P Faure M Sardin 2017 Evidence of colloidal transport of PAHs during column experiments run with contaminated soil samples Environ Sci and Poll Res https://doi.org/10.1007/ s11356-017-8586-4

12. P Berg van den E Huerta-Lwanga F Corradini V Geissen 2020 Sewage sludge application as a vehicle for microplastics in eastern Spanish agricultural soils Environ Pollut https://doi.org/10.1016/j.envpol.2020. 114198

13. Bergmann M, Peeken I, Beyer B, Krumpen T, Primpke S, Tekman MB, Gerdts G. Vast quantities of microplastics in Arctic Sea Ice-a prime temporary sink for plastic litter and a medium of transport. Fate Impact Microplastics Marine Ecosyst 2016: 75-76.

14. N Beriot J Peek R Zornoza V Geissen E Huerta-Lwanga 2021 Low density-microplastics detected in sheep faeces and soil: a case study from the intensive vegetable farming in Southeast Spain Sci Total Environ https://doi.org/10.1016/j.scitotenv.2020.142653

15. N Beriot P Zomer R Zornoza V Geissen 2020 A laboratory comparison of the interactions between three plastic mulch types and 38 active substances found in pesticides PeerJ https://doi.org/10.7717/peerj.9876

16. E Besseling JTK Quik M Sun AA Koelmans 2017 Fate of nano- and microplastic in freshwater systems: a modeling study Environ Pollut https:// doi.org/10.1016/j.envpol.2016.10.001

17. Biothop. Biotwine hop waste transformation into novel product assortments for packaging and horticulture sector. https://www.life-bioth op.eu/wp-content/uploads/2019/12/BioTHOP-FLYER_ENG_Czech.pdf. Accessed May 2021

18. M Blasing W Amelung 2018 Plastics in soil: analytical methods and possible sources Sci Total Environ https://doi.org/10.1016/j.scitotenv.2017. 08.086
19. Brandes $E$, Henseler M, Kreins P. Identifying hot-spots for microplastic contamination in agricultural soils — a spatial modelling approach for Germany. Environ Res Lett. 2021;16(10):104041.

20. Brandes E, Cieplik S, Fiener P, Henseler M, Herrmann F, Klasmeier J, Kreins P, PiehI S, Shiravani G, Wendland F, Wurpts A. Modellbasierte Forschung zu Mikroplastik in der Umwelt. 2020.

21. Braun T, Ehrlich L, Henrich W, Koeppel S, Lomako I, Schwabl P, Liebmann B. Detection of microplastic in human placenta and meconium in a clinical setting. Pharmaceutics. 2021;13(7):921. https://doi.org/10. 3390/pharmaceutics13070921.

22. D Briassoulis M Hiskakis E Babou 2013 Technical specifications for mechanical recycling of agricultural plastic waste Waste Manag https://doi.org/10.1016/j.wasman.2013.03.004

23. JE Bullard A Ockelford P O'Brien CM Neuman 2021 Preferential transport of microplastics by wind Atmos Environ https://doi.org/10. 1016/j.atmosenv.2020.118038

24. C Campanale C Massarelli I Savino V Locaputo VF Uricchio 2020 A detailed review study on potential effects of microplastics and additives of concern on human health Int J Environ Res Public Health https://doi.org/10.3390/ijerph17041212

25. Carr SA, Liu J, Tesoro AG. Transport and fate of microplastic particles in wastewater treatment plants. Water Res. 2016;91:174-82. https:// doi.org/10.1016/j.watres.2016.01.002.

26. YR Choi YN Kim JH Yoon N Dickinson KH Kim 2020 Plastic contamination of forest, urban, and agricultural soils: a case study of Yeoju City in the Republic of Korea J Soils Sediments https://doi.org/10.1007/ s11368-020-02759-0

27. M Chopra B Koul 2020 Comparative assessment of different types of mulching in various crops: a review Plant Arch 2016201626

28. F Corradini F Casado V Leiva E Huerta-Lwanga V Geissen 2021 Microplastics occurrence and frequency in soils under different land uses on a regional scale Sci Total Environ https://doi.org/10.1016/j.scito tenv.2020.141917

29. F Corradini P Meza R Eguiluz F Casado E Huerta-Lwanga V Geissen 2019 Evidence of microplastic accumulation in agricultural soils from sewage sludge disposal Sci Total Environ https://doi.org/10.1016/j. scitotenv.2019.03.368

30. Crawford CB, Quinn B. 9-microplastic separation techniques. Microplastic pollutants. Elsevier; 2017. p. 203-18. https://doi.org/10.1016/ B978-0-12-809406-8.00009-8

31. J Crossman RR Hurley M Futter L Nizzetto 2020 Transfer and transport of microplastics from biosolids to agricultural soils and the wider environment SciTotal Environ. https://doi.org/10.1016/j.scitotenv. 2020.138334

32. Dahl M, Bergman S, Björk M, Diaz-Almela E, Granberg M, Gullström M, et al. A temporal record of microplastic pollution in Mediterranean seagrass soils. Environ Pollut. 2021;273: 116451. https://doi.org/10. 1016/j.envpol.2021.116451.

33. L Ding S Zhang X Wang X Yang C Zhang Y Qi X Guo 2020 The occurrence and distribution characteristics of microplastics in the agricultural soils of Shaanxi Province, in North-Western China Sci Total Environ https://doi.org/10.1016/j.scitotenv.2020.137525

34. DC Dioses-Salinas CI Pizarro-Ortega GE De-la-Torre 2020 A methodological approach of the current literature on microplastic contamination in terrestrial environments: current knowledge and baseline considerations Sci Total Environ https://doi.org/10.1016/j.scitotenv. 2020.139164

35. Dong Y, Gao M, Song Z, Qiu W. As (III) adsorption onto different-sized polystyrene microplastic particles and its mechanism. Chemosphere. 2020;239: 124792. https://doi.org/10.1016/j.chemosphere.2019. 124792.

36. S Dong J Xia L Sheng W Wang H Liu B Gao 2021 Transport characteristics of fragmental polyethylene glycol terephthalate (PET) microplastics in porous media under various chemical conditions Chemosphere https://doi.org/10.1016/j.chemosphere.2021.130214

37. F Du H Cai Q Zhang Q Chen H Shi 2020 Microplastics in take-out food containers J Hazard Mater https://doi.org/10.1016/j.jhazmat.2020. 122969

38. K Duis A Coors 2016 Microplastics in the aquatic and terrestrial environment: sources (with a specific focus on personal care products), fate and effects Environ Sci Eur https://doi.org/10.1186/s12302-015-0069-y 
39. E Espí A Salmerón A Fontecha Y García Al Real 2006 Plastic films for agricultural applications J Plast Film Sheet https://doi.org/10.1177/87560 87906064220

40. Y Fan K Zheng Z Zhu G Chen X Peng 2019 Distribution, sedimentary record, and persistence of microplastics in the Pearl River catchment China Environ Poll https://doi.org/10.1016/j.envpol.2019.05.056

41. S Feng H Lu PTian Y Xue J Lu M Tang W Feng 2020 Analysis of microplastics in a remote region of the Tibetan Plateau: implications for natural environmental response to human activities Sci Total Environ https://doi.org/10.1016/j.scitotenv.2020.140087

42. OH Fred-Ahmadu G Bhagwat I Oluyoye NU Benson OO Ayejuyo T Palanisami 2020 Interaction of chemical contaminants with microplas tics: principles and perspectives Sci Total Environ https://doi.org/10. 1016/j.scitotenv.2019.135978

43. JPGL Frias R Nash 2019 Microplastics: finding a consensus on the definition Mar Pollut Bull https://doi.org/10.1016/..marpolbul.2018.11.022

44. A Fucic KS Galea RC Duca MEI Yamani N Frery L Godderis TI Halldorsson I lavicoli S Ndaw E Ribeiro S Viegas H Moshammer 2018 Potential health risk of endocrine disruptors in construction sector and plastics industry: a new paradigm in occupational health J Environ Res Public Health https://doi.org/10.3390/ijerph15061229

45. GESAMP. Sources, fate and effects of microplastics in the marine environment: a global assessment. Kershaw PJ (ed). Rep Stud GESAMP No. 90, 96 pp; 2015

46. OD Gaonkar IM Nambi SK Govindarajan 2019 Soil organic amendments: impacts on sorption of organophosphate pesticides on an alluvial soil J Soils Sed https://doi.org/10.1007/s11368-018-2080-6

47. C García-Delgado JM Marín-Benito MJ Sánchez-Martín MS RodríguezCruz 2020 Organic carbon nature determines the capacity of organic amendments to adsorb pesticides in soil J Hazard Mater https://doi. org/10.1016/j.jhazmat.2020.122162

48. J Ge H Li P Liu Z Zhang Z Ouyang X Guo 2021 Review of the toxic effect of microplastics on terrestrial and aquatic plants Sci Total Environ https://doi.org/10.1016/j.scitotenv.2021.148333

49. S Ghimire M Flury EJ Scheenstra CA Miles 2020 Sampling and degradation of biodegradable plastic and paper mulches in field after tillage incorporation Sci Total Environ https://doi.org/10.1016/j.scitotenv.2019. 135577

50. J Gigault A Halle ter M Baudrimont P-Y Pascal F Gauffre T-L Phi H Hadri El B Grass S Reynaud 2018 Current opinion: what is a nanoplastic? Environ Pollut https://doi.org/10.1016/j.envpol.2018.01.024

51. S Guerrini G Borreani H Voojis 2017 Biodegradable materials in agriculture: case histories and perspectives M Malinconico Eds Soil degradable bioplastics for a sustainable modern agriculture Springer, Berlin Heidelberg Berlin 3565

52. J Gui Y Sun J Wang X Chen S Zhang D Wu 2021 Microplastics in composting of rural domestic waste: abundance, characteristics, and release from the surface of macroplastics Environ Poll https://doi.org/10.1016/j. envpol.2021.116553

53. Guo L, Jury WA, Wagenet RJ, Flury M. Dependence of pesticide degradation on sorption: nonequilibrium model and application to soil reactors. J Contam Hydrol. 2000;43(1):45-62. https://doi.org/10.1016/ S0169-7722(99)00097-2.

54. TP Haider C Völker J Kramm K Landfester FR Wurm 2019 Plastics of the future. The impact of biodegradable polymers on the environment and on societ Angew Chem Int Ed https://doi.org/10.1002/anie.201805766

55. P Hanachi S Kazemi S Zivary S Karbalaei SA Ghadami 2021 The effect of polyethylene terephthalate and abamectin on oxidative damages and expression of vtg and cypla genes in juvenile zebrafish Environ Nanotech Monit Manage https://doi.org/10.1016/j.enmm.2021.100565

56. IK Harms T Diekötter S Troegel M Lenz 2021 Amount, distribution and composition of large microplastics in typical agricultural soils in Northern Germany Sci Total Environ https://doi.org/10.1016/j.scitotenv.2020. 143615

57. DG Hayes LC Wadsworth HY Sintim M Flury M English S Schaeffer AM Saxton 2017 Effect of diverse weathering conditions on the physicochemical properties of biodegradable plastic mulches Polym Testing https://doi.org/10.1016/j.polymertesting.2017.07.027

58. MS Helmberger LKTiemann MJ Grieshop 2019 Towards an ecology of soil microplastics Func Ecol https://doi.org/10.1111/1365-2435.13495
59. L Hermabessiere A Dehaut I Paul-Pont C Lacroix R Jezequel P Soudant G Duflos 2017 Occurrence and effects of plastic additives on marine environments and organisms: a review Chemosphere https://doi.org/ 10.1016/j.chemosphere.2017.05.096

60. CE Hernandez SWitter 1996 Evaluating and managing the environmental impact of banana production in costa rica: a systems approach Ambio 25(3):171-178

61. ME Hodson CA Duffus-Hodson A Clark MT Prendergast-Miller KL Thorpe 2017 Plastic bag derived-microplastics as a vector for metal exposure in terrestrial invertebrates Environ Sci Technol https://doi.org/10.1021/acs. est.7b00635

62. D Hogg A Gibbs S Hann S Ettlinger 2016 The impact of the use of "oxo-degradable" plastic on the environment. European Commission Directorate-General for Environment European Union Luxembourg

63. AA Horton A Walton DJ Spurgeon E Lahive C Svendsen 2017 Microplastics in freshwater and terrestrial environments: evaluating the current understanding to identify the knowledge gaps and future research priorities Sci Total Environ https://doi.org/10.1016/j.marpolbul.2016.09. 004

64. Huang Q, Liu WQ, Jia CR, Yan J. Wang Agricultural plastic mulching as a source of microplastics in the terrestrial environment. Environ Pollut. 2020;260:114096. https://doi.org/10.1016/j.envpol.2020.114096.

65. Y Huang Q Lui W Jia C Yan J Wang 2020 Agricultural plastic mulching as a source of microplastics in the terrestrial environment Environ Pollut https://doi.org/10.1016/j.envpol.2020.114096

66. Huerta Lwanga E, Gertsen H, Gooren H, Peters P, Salánki T, Van Der Ploeg M, et al. Microplastics in the terrestrial ecosystem: implications for Lumbricus terrestris (Oligochaeta, Lumbricidae). Environ Sci Technol. 2016;50(5):2685-91. https://doi.org/10.1021/acs.est.5b05478.

67. Huerta Lwanga EH, Gertsen H, Gooren H, Peters P, Salánki T, van der Ploeg M, et al. Incorporation of microplastics from litter into burrows of Lumbricus terrestris. Environ Pollut. 2017;220:523-31. https://doi.org/ 10.1016/j.envpol.2016.09.096.

68. Huerta Lwanga EH, Vega JM, Quej VK, de los Angeles Chi J, Del Cid $\mathrm{LS}, \mathrm{Chi} C$, et al. Field evidence for transfer of plastic debris along a terrestrial food chain. Sci Rep. 2017;7(1):1-7. https://doi.org/10.1038/ s41598-017-14588-2Y.

69. RR Hurley L Nizzetto 2018 Fate and occurrence of micro(nano)plastics in soils: Knowledge gaps and possible risks Curr Opin Environ Sci Health https://doi.org/10.1016/j.coesh.2017.10.006

70. Hüffer T, Metzelder F, Sigmund G, Slawek S, Schmidt TC, Hofmann T. Polyethylene microplastics influence the transport of organic contaminants in soil. Sci Total Environ. 2019;657:242-7. https://doi.org/10. 1016/j.scitotenv.2018.12.047.

71. JR Jambeck R Geyer C Wilcox TR Siegler M Perryman A Andrady R Narayan LK Lavender 2015 Plastic waste inputs from land into the ocean Science https://doi.org/10.1126/science.1260352

72. XJ Jiang W Liu E Wang T Zhou P Xin 2017 Residual plastic mulch fragments effects on soil physical properties and water flow behavior in the Minqin Oasis, northwestern China Soil and Till Res https://doi.org/10. 1016/j.still.2016.10.011

73. S Karbalaei P Hanachi G Rafiee P Seifori TR Walker 2021 Toxicity of polystyrene microplastics on juvenile Oncorhynchus mykiss (rainbow trout) after individual and combined exposure with chlorpyrifos $J$ of Haz Mat https://doi.org/10.1016/j.jhazmat.2020.123980

74. S Kasirajan M Ngouajio 2012 Polyethylene and biodegradable mulches for agricultural applications: a review Agron Sustain Dev https://doi. org/10.1007/s13593-011-0068-3

75. N Katsumi T Kusube S Nagao H Okochi 2020 The role of coated fertilizer used in paddy fields as a source of microplastics in the marine environment Mar Pollut Bull https://doi.org/10.1016/j.marpolbul.2020.111727

76. N Katsumi T Kusube S Nagao H Okochi 2021 Accumulation of microcapsules derived from coated fertilizer in paddy fields Chemosphere https://doi.org/10.1016/j.chemosphere.2020.129185

77. D Kawecki B Nowack 2019 Polymer-specific modeling of the environmental emissions of seven commodity plastics as macro- and microplastics Environ Sci Tech https://doi.org/10.1021/acs.est.9b02900

78. D Kawecki B Nowack 2020 A proxy-based approach to predict spatially resolved emissions of macro- and microplastic to the environment Sci Total Environ https://doi.org/10.1016/j.scitotenv.2020.141137 
79. T Kijchavengkul R Auras 2008 Compostability of polymers Polym Int https://doi.org/10.1002/pi.2420

80. K Kik B Bukowska P Sicinska 2020 Polystyrene nanoparticles: Sources, occurrence in the environment, distribution in tissues, accumulation and toxicity to various organisms Environ Pollut https://doi.org/10. 1016/j.envpol.2020.114297

81. SK Kim JS Kim H Lee HJ Lee 2021 Abundance and characteristics of microplastics in soils with different agricultural practices: importance of sources with internal origin and environmental fate J Hazard Mater https://doi.org/10.1016/j.jhazmat.2020.123997

82. H Kim JY Lee 2020 Emerging concerns about microplastic pollution on groundwater in South Korea Sustainability https://doi.org/10.3390/ su12135275

83. T Kiss S Fórián G Szatmári G Sipos 2021 Spatial distribution of microplastics in the fluvial sediments of a transboundary river-a case study of the Tisza River in Central Europe Sci Total Environ https://doi.org/10. 1016/j.scitotenv.2021.147306

84. Y Kiyama K Miyahara Y Ohshima 2012 Active uptake of artificial particles in the nematode Caenorhabditis elegans J Exp Biol https://doi.org/10. 1242/jeb.06719950

85. M Kooi E Besseling C Kroeze AP Wenzel van AA Koelmans 2018 Modeling the fate and transport of plastic debris in freshwaters: review and guidance, freshwater microplastics Springer 125152 https://doi.org/10. 1007/978-3-319-61615-5 14

86. VS Koutnik J Leonard S Alkidim FJ DePrima S Ravi EMV Hoek K Mohanty 2021 Distribution of microplastics in soil and freshwater environments: global analysis and framework for transport modeling Environ Pollut https://doi.org/10.1016/j.envpol.2021.116552

87. MC Krueger H Harms D Schlosser 2015 Prospects for microbiological solutions to environmental pollution with plastics Appl Microbiol Biotechnol https://doi.org/10.1007/s00253-015-6879-4

88. N Kärkkäinen M Sillanpää 2021 Quantification of different microplastic fibres discharged from textiles in machine wash and tumble drying Environ Sci Pollut R https://doi.org/10.1007/s11356-020-11988-2

89. Lahive E, Walton A, Horton AA, Spurgeon DJ, Svendsen C. Microplastic particles reduce reproduction in the terrestrial worm Enchytraeus crypticus in a soil exposure. Environ Pollut. 2019;255:113174. https://doi.org/ 10.1016/j.envpol.2019.113174.

90. L Lebreton A Andrady 2019 Future scenarios of global plastic waste generation and disposal Palgrave Commun https://doi.org/10.1057/ s41599-018-0212-7

91. LL Lei S Wu S Lu L Shibo M Liu Y Song Z Fu H Shi KM Raley-Susman D He 2018 Microplastic particles cause intestinal damage and other adverse effects in zebrafish Danio rerio and nematode Caenorhabditis elegans Sci Tot Environ https://doi.org/10.1016/j.scitotenv.2017.11.103

92. W Li R Wufuer J Duo S Wang Y Luo D Zhang X Pan 2020 Microplastics in agricultural soils: extraction and characterization after different periods of polythene film mulching in an arid region Sci Total Environ https:// doi.org/10.1016/j.scitotenv.2020.141420

93. Q Li A Zeng X Jiang X Gu 2021 Are microplastics correlated to phthalates in facility agriculture soil? J Hazard Mater https://doi.org/10.1016/j. jhazmat.2021.125164

94. Liu EK, He WQ, Yan CR. 'White revolution'to 'white pollution'—agricultural plastic film mulch in China. Environ Res Lett. 2014;9(9):091001.

95. Liu P, Lu K, Li J, Wu X, Qian L, Wang M, Gao S. Effect of aging on adsorption behavior of polystyrene microplastics for pharmaceuticals: adsorption mechanism and role of aging intermediates. J Hazard Mater. 2020;384:121193. https://doi.org/10.1016/j.jhazmat.2019.121193.

96. M Liu S Lu Y Song L Lei J Hu W Lv W Zhou C Cao H Shi X Yang D He 2018 Microplastic and mesoplastic pollution in farmland soils in suburbs of Shanghai China Environ Pollut https://doi.org/10.1016/j.envpol. 2018.07.051

97. F Liu KB Olesen AR Borregaard J Vollertsen 2019 Microplastics in urban and highway stormwater retention ponds Sci Total Environ https://doi. org/10.1016/j.scitotenv.2019.03.416

98. N Lutz J Fogarty A Rate 2021 Accumulation and potential for transport of microplastics in stormwater drains into marine environments, Perth region, Western Australia Mar Pollut Bull https://doi.org/10.1016/j. marpolbul.2021.112362

99. Lv X, Dong Q, Zuo Z, Liu Y, Huang X, Wu WM. Microplastics in a municipal wastewater treatment plant: Fate, dynamic distribution, removal efficiencies, and control strategies. J Clean Prod. 2019;225:579-86. https://doi.org/10.1016/j.jclepro.2019.03.321.

100. S Maaß D Daphi A Lehmann MC Rillig 2017 Transport of microplastics by two collembolan species Environ Pollut https://doi.org/10.1016/j. envpol.2017.03.009

101. Mahon AM, O'Connell B, Healy MG, O'Connor I, Officer R, Nash R, Morrison L. Microplastics in sewage sludge: effects of treatment. Environ Sci Technol. 2017;51 (2):810-8. https://doi.org/10.1021/acs.est.6b04048.

102. FK Mammo ID Amoah KM Gani L Pillay SK Ratha F Bux S Kumari 2020 Microplastics in the environment: Interactions with microbes and chemical contaminants Sci Total Environ https://doi.org/10.1016/j.scito tenv.2020.140518

103. A McCormick TJ Hoellein SA Mason J Schluep JJ Kelly 2014 Microplastic is an abundant and distinct microbial habitat in an urban river Environ Sci Tech https://doi.org/10.1021/es503610r

104. F Meng T Fan X Yang M Riksen M Xu V Geissen 2020 Effects of plastic mulching on the accumulation and distribution of macro and micro plastics in soils of two farming systems in Northwest China PeerJ https://doi.org/10.7717/peerj.10375

105. Miles C, DeVetter L, Ghimire S, Hayes DG. Suitability of biodegradable plastic mulches for organic and sustainable agricultural production systems. HortScience. 2017;52(1):10-5. https://doi.org/10.21273/HORTS Cl11249-16.

106. SM Mintenig MGJ Loder S Primpke G Gerdts 2019 Low numbers of microplastics detected in drinking water from ground water sources Sci Total Environ https://doi.org/10.1016/j.scitotenv.2018.08.178

107. P Miros-Kudra K Gzyra-Jagiela M Kudra 2021 Physicochemical assessment of the biodegradability of agricultural nonwovens made of PLA Fibres Text East Eur https://doi.org/10.5604/01.3001.0014.2398

108. FA Monikh MG Vijver Z Guo P Zhang GK Darbha WJ Peijnenburg 2020 Metal sorption onto nanoscale plastic debris and trojan horse effects in Daphnia magna: role of dissolved organic matter Water Res https://doi. org/10.1016/j.watres.2020.116410

109. L Nizzetto D Butterfield G Bussi PG Whitehead MN Futter 2016 A theoretical assessment of microplastic transport in river catchments and their retention by soils and river sediments Environ Sci Process Impacts https://doi.org/10.1039/c6em00206d

110. L Nizzetto S Langaas M Futter 2016 Pollution: do microplastics spill on to farm soils? Nature https://doi.org/10.1038/537488b

111. D O'Connor S Pan Z Shen Y Song Y Jin WM Wu D Hou 2019 Microplastics undergo accelerated vertical migration in sand soil due to small size and wet-dry cycles Environ Pollut https://doi.org/10.1016/j.envpol. 2019.03.092

112. M Oever van den K Molenveld M Zee van der H Bos 2017 Bio-based and biodegradable plastics: facts and figures: focus on food packaging in the Netherlands Wageningen Food \& Biobased Research Wageningen

113. ED Okoffo E Donner SP McGrath BJ Tscharke JW O'Brien S O'Brien F Ribeiro SD Burrows T Toapanta C Rauert S Samanipour JF Mueller KV Thomas 2021 Plastics in biosolids from 1950 to 2016: a function of global plastic production and consumption Water Res https://doi.org/ 10.1016/j.watres.2021.117367

114. PN Owens 2020 Soil erosion and sediment dynamics in the Anthropocene: a review of human impacts during a period of rapid global environmental change J Soils Sediments https://doi.org/10.1007/ s11368-020-02815-9

115. SV Panno WR Kelly J Scott W Zheng RE McNeish N Holm TJ Hoellein EL Baranski 2019 Microplastic contamination in karst groundwater systems Ground Water https://doi.org/10.1111/gwat.12862

116. R Peñalver I Costa-Gomez N Arroyo-Manzanares JM Moreno I LopezGarcia S Moreno-Grau CM Hernandez 2021 Assessing the level of airborne polystyrene microplastics using thermogravimetry-mass spectrometry: results for an agricultural area Sci Total Environ https:// doi.org/10.1016/.jscitotenv.2021.147656

117. S Piehl A Leibner MGJ Löder R Dris C Bogner C Laforsch 2018 Identification and quantification of macro- and microplastics on an agricultural farmland Sci Rep https://doi.org/10.1038/s41598-018-36172-y

118. Plastic Europe. Plastics - the facts 2020. An analysis of European plastics production, demand and waste data. Published online at PlasticsEurope.org. 2020.https://www.plasticseurope.org/es/resources/publi cations/4312-plastics-facts-2020. Accessed 24 May 2021. 
119. JC Prata 2018 Airborne microplastics: consequences to human health? Environ Pollut https://doi.org/10.1016/j.envpol.2017.11.043

120. Prata JC, da Costa JP, Lopes I, Duarte AC, Rocha-Santos T. Environmental exposure to microplastics: an overview on possible human health effects. Sci Total Environ. 2020;702:134455. https://doi.org/10.1016/j. scitotenv.2019.134455

121. J Prunier L Maurice E Perez I Gigault A-CP Wickmann M Davranche A Ter Halle 2019 Trace metals in polyethylene debris from the North Atlantic subtropical gyre Environ Pollut https://doi.org/10.1016/j. envpol.2018.10.043

122. Y Qi N Beriot G Gort E Huerta Lwanga H Gooren X Yang V Geissen 2020 Impact of plastic mulch film debris on soil physicochemical and hydrological properties Environ Pollut https://doi.org/10.1016/j.envpol.2020. 115097

123. R Qi DL Jones Z Li Q Liu C Yan 2020 Behavior of microplastics and plastic film residues in the soil environment: a critical review Sci Total Environ https://doi.org/10.1016/j.scitotenv.2019.134722

124. Y Qi X Yang AM Pelaez E Huerta Lwanga N Beriot H Gertsen P Garbeva V Geissen 2018 Macro- and micro- plastics in soil-plant system: effects of plastic mulch film residues on wheat (Triticum aestivum) growth Sci Total Environ https://doi.org/10.1016/j.scitotenv.2018.07.229

125. P Rai S Mehrotra S Priya E Gnansounou SK Sharma 2021 Recent advances in the sustainable design and applications of biodegradable polymers Bioresource Technol https://doi.org/10.1016/j.biortech.2021. 124739

126. H Ranjeet R Amol J Khajal C Jhanvi S Abhay 2019 Studies of plastic Bezoar ingestion in free range axis deer in summer J Anim Res https:// doi.org/10.30954/2277-940X.02.2019.26

127. V Re 2019 Shedding light on the invisible: addressing the potential for groundwater contamination by plastic microfibers Hydrogeol J https:// doi.org/10.1007/s10040-019-01998-x

128. R Rehm T Zeyer A Schmidt P Fiener 2021 Soil erosion as transport pathway of microplastic from agriculture soils to aquatic ecosystems Sci Total Environ https://doi.org/10.1016/j.scitotenv.2021.148774

129. M Rezaei MJPM Riksen E Sirjani A Sameni V Geissen 2019 Wind erosion as a driver for transport of light density microplastics Sci Total Environ https://doi.org/10.1016/j.scitotenv.2019.02.382

130. MC Rillig 2012 Microplastic in terrestrial ecosystems and the soil? Environ Sci Technol https://doi.org/10.1021/es302011r

131. MC Rillig R Ingraffia AA Souza Machado de 2017 Microplastic incorporation into soil in agroecosystems Front Plant Sci 8. https://doi.org/10. 3389/fpls.2017.01805

132. CM Rochman BT Hentschel SJ Teh 2014 Long-term sorption of metals is similar among plastic types: implications for plastic debris in aquatic environments PLoS ONE https://doi.org/10.1371/journal.pone.0085433

133. CM Rochman T Hoellein 2020 The global odyssey of plastic pollution Science https://doi.org/10.1126/science.abc4428

134. MO Rodrigues N Abrantes FJM Gonçalves H Nogueira JC Marques AMM Gonçalves 2018 Spatial and temporal distribution of microplastics in water and sediments of a freshwater system (Antuã River, Portugal) Sci Total Environ https://doi.org/10.1016/j.scitotenv.2018.03.233

135. Rodriguez-Seijo A, Lourenço J, Rocha-Santos TAP, Da Costa J, Duarte AC, Vala H, Pereira R. Histopathological and molecular effects of microplastics in Eisenia andrei Bouché. Environ Pollut. 2017;220:495-503. https:// doi.org/10.1016/.j.envpol.2016.09.092.

136. Roedel MJ. The molecular structure of polyethylene. I. Chain branching in polyethylene during polymerization 1. J Am Chem Soc. 1953;75(24):6110-2.

137. KL Rogers JA Carreres-Calabuig E Gorokhova NR Posth 2020 Micro-bymicro interactions: how microorganisms influence the fate of marine microplastics Limnol Oceanogr https://doi.org/10.1002/lol2.10136

138. F Sadegh-Zadeh S Abd Wahid B Jalili 2017 Sorption, degradation and leaching of pesticides in soils amended with organic matter: a review Adv in Environ Tech https://doi.org/10.22104/AET.2017.1740.1100

139. JC Sanchez-Hernandez 2021 A toxicological perspective of plastic biodegradation by insect larvae Comp Biochem Physiol C Toxicol Pharmacol https://doi.org/10.1016/j.cbpc.2021.109117

140. M Sander 2019 Biodegradation of polymeric mulch films in agricultural soils: concepts, knowledge gaps, and future research directions Environ Sci \& Tech https://doi.org/10.1021/acs.est.8b05208
141. B Schothorst van N Beriot E Huerta Lwanga V Geissen 2021 Sources of light density microplastic related to two agricultural practices: the use of compost and plastic mulch'Environments https://doi.org/10.3390/ environments8040036

142. S Seidensticker P Grathwohl J Lamprecht C Zarfl 2018 A combined experimental and modeling study to evaluate $\mathrm{pH}$-dependent sorption of polar and non-polar compounds to polyethylene and polystyrene microplastics Environ Sci Eur https://doi.org/10.1186/ s12302-018-0155-z

143. S Selke R Auras TA Nguyen E Castro Aguirre R Cheruvathur Y Liu 2015 Evaluation of biodegradation-promoting additives for plastics Environ Sci \& Tech https://doi.org/10.1021/es504258u

144. Selonen S, Dolar A, Kokalj AJ, Skalar T, Dolcet LP, Hurley R, Van Gestel CA. Exploring the impacts of plastics in soil-the effects of polyester textile fibers on soil invertebrates. Sci Total Environ. 2020;700:134451. https:// doi.org/10.1016/j.scitotenv.2019.134451.

145. F Sergio J Blas G Blanco A Tanferna L López JA Lemus F Hiraldo 2011 Raptor nest decorations are a reliable threat against conspecifics Science https://doi.org/10.1126/science.1199422

146. Serrano-Ruiz H, Martin-Closas L, Pelacho AM. Biodegradable plastic mulches: Impact on the agricultural biotic environment. Sci Total Environ. 2021;750:141228. https://doi.org/10.1016/j.scitotenv.2020.141228.

147. PM Silva MA Nanny 2020 Impact of microplastic fibers from the degradation of nonwoven synthetic textiles to the magdalena river water column and river sediments by the city of Neiva, Huila (Colombia) Water (Switzerland) https://doi.org/10.3390/W12041210

148. HY Sintim M Flury 2017 Is Biodegradable plastic mulch the solution to agriculture's plastic problem? Environ Sci \& Tech https://doi.org/10. 1021/acs.est.6b06042

149. Song Y, Cao C, Qiu R, Hu J, Liu M, Lu S, et al. Uptake and adverse effects of polyethylene terephthalate microplastics fibers on terrestrial snails (Achatina fulica) after soil exposure. Environ Pollut. 2019;250:447-55. https://doi.org/10.1016/..envpol.2019.04.066.

150. AA Souza Machado de W Kloas C Zarfl S Hempel MC Rillig 2018 Microplastics as an emerging threat to terrestrial ecosystems Glob Change Biol. https://doi.org/10.1111/gcb.14020

151. AA Souza Machado de CW Lau W Kloas J Bergmann JB Bachelier E Faltin R Becker AS Görlich MC Rillig 2019 Microplastics can change soil properties and affect plant performance Environ Sci Tech https://doi. org/10.1021/acs.est.9b01339

152. AA Souza Machado de CW Lau J Till W Kloas A Lehmann R Becker MC Rillig 2018 Impacts of microplastics on the soil biophysical environment Environ Sci \& Tech https://doi.org/10.1021/acs.est.8b02212

153. Statista. Global plastic production 1950-2020. 2021.https://www.stati sta.com/statistics/282732/global-production-of-plastics-since-1950/ Accessed 8 Jul 2021.

154. Su S, Zhou S, Lin G. Existence of microplastics in soil and groundwater in Jiaodong Peninsula. E3S Web of Conferences. 2021. Doi:https://doi. org/10.1051/e3sconf/202125102045.

155. Q Sun J Li C Wang A Chen Y You S Yang H Liu G Jiang Y Wu Y Li 2022 Research progress on distribution, sources, identification, toxicity, and biodegradation of microplastics in the ocean, freshwater, and soil environment Front Environ Sci Eng https://doi.org/10.1007/ s11783-021-1429-z

156. Svensk Ensilageplast Retur AB. http://svepretur.se/en/our-services/ proceed-as-follows/. Accessed June 2021.

157. CA Tender De LI Devriese A Haegeman S Maes T Ruttink P Dawyndt 2015 Environ Sci Tech https://doi.org/10.1021/acs.est.5b01093

158. L Toni De F Tisato R Seraglia M Roverso V Gandin C Marzano R Padrini C Foresta 2017 Phthalates and heavy metals as endocrine disruptors in food: a study on pre-packed coffee products Toxicol Rep https://doi. org/10.1016/j.toxrep.2017.05.004

159. KM Unice MP Weeber MM Abramson RCD Reid JAG Gils van AA Markus AD Vethaak JM Panko 2019 Characterizing export of land-based microplastics to the estuary-Part l: application of integrated geospatial microplastic transport models to assess tire and road wear particles in the Seine watershed Sci of Tot Environ https://doi.org/10.1016/j.scito tenv.2018.07.368

160. KM Unice MP Weeber MM Abramson RCD Reid JAG Gils van AA Markus AD Vethaak JM Panko 2019 Characterizing export of land-based microplastics to the estuary_-Part II: sensitivity analysis of an integrated 
geospatial microplastic transport modeling assessment of tire and road wear particles Sci Tot Environ https://doi.org/10.1016/j.scitotenv.2018. 08.301

161. AK Urbanek W Rymowicz AM Mirończuk 2018 Degradation of plastics and plastic-degrading bacteria in cold marine habitats Appl Microbiol Biotechnol https://doi.org/10.1007/s00253-018-9195-y

162. KWaldschlaeger S Lechthaler $\mathrm{G}$ Stauch H Schuttrumpf 2020 The way of microplastic through the environment-application of the sourcepathway-receptor model (review) Sci Total Environ https://doi.org/10 1016/j.scitotenv.2020.136584

163. KWaldschlaeger H Schuttrumpf 2020 Infiltration behavior of microplastic particles with different densities, sizes, and shapes-from glass spheres to natural sediments Environ Sci Technol https://doi.org/10. 1021/acs.est.0c01722

164. Y Wan C Wu Q Xue X Hui 2019 Effects of plastic contamination on water evaporation and desiccation cracking in soil Sci Total Environ https:// doi.org/10.1016/j.scitotenv.2018.11.123

165. L Wang XG Li J LV T Fu Q Ma W Song YP Wang F-M Li 2017 Continuous plastic-film mulching increases soil aggregation but decreases soil pH in semiarid areas of China Soil Till Res https://doi.org/10.1016/.jstill.2016. 11.004

166. J Wang X Liu Y LiT Powell X Wang G Wang P Zhang 2019 Microplastics as contaminants in the soil environment: a mini-review Sci Total Environ https://doi.org/10.1016/j.scitotenv.2019.07.209

167. T Wang L Wang Q Chen N Kalogerakis R Ji Y Ma 2020 Interactions between microplastics and organic pollutants: effects on toxicity, bioaccumulation, degradation, and transport Sci Total Environ https:// doi.org/10.1016/j.scitotenv.2020.142427

168. Wang C, Zhao J, Xing B. Environmental source, fate, and toxicity of microplastics. J Hazard Mater. 2021;407: 124357. https://doi.org/10. 1016/j.j.hazmat.2020.124357.

169. N Weithmann JN Möller MGJ Löder S Piehl C Laforsch R Freitag 2018 Organic fertilizer as a vehicle for the entry of microplastic into the environment Sci Adv https://doi.org/10.1126/sciadv.aap8060

170. Weithmann N, Möller JN, Löder MG, Piehl S, Laforsch C, Freitag R. Organic fertilizer as a vehicle for the entry of microplastic into the environment. Sci Adv. 2018;4(4):eaap8060. https://doi.org/10.1126/sciadv. aap8060.

171. Weng YX, Jin YJ, Meng QY, Wang L, Zhang M, Wang YZ. Biodegradation behavior of poly (butylene adipate-co-terephthalate)(PBAT), poly (lactic acid)(PLA), and their blend under soil conditions. Polym Testing 2013;32(5):918-26. https://doi.org/10.1016/j.polymertesting.2013.05. 001.

172. J Wijnen van AMJ Ragas C Kroeze 2019 Modelling global river export of microplastics to the marine environment: sources and future trends Sci Tot Environ https://doi.org/10.1016/j.scitotenv.2019.04.078

173. FM Windsor I Durance AA Horton RC Thompson CR Tyler SJ Ormerod 2019 A catchment-scale perspective of plastic pollution Glob Change Biol https://doi.org/10.1111/gcb.14572

174. P Wu J Huang Y Zheng Y Yang Y Zhang F He H Chen G Quan J Yan T Li B Gao 2019 Environmental occurrences, fate, and impacts of microplastics Ecotox Environ Saf https://doi.org/10.1016/j.ecoenv.2019.109612

175. B Xu F Liu Z Cryder D Huang Z Lu Y He H Wang Z Lu PC Brookes C Tang J Gan J Xu 2020 Microplastics in the soil environment: occurrence, risks, interactions and fate-a review Crit Rev Environ Sci Tech https://doi. org/10.1080/10643389.2019.1694822

176. J Jang R Li Q Zhou L Li Y Lo C Tu X Zhao K Xiong P Christie Y Luo 2021 Abundance and morphology of microplastics in an agricultural soil following long-term repeated application of pig manure Environ Pollut https://doi.org/10.1016/j.envpol.2020.116028

177. Yang X, Lwanga EH, Bemani A, Gertsen H, Salanki T, Guo X, et al. Biogenic transport of glyphosate in the presence of LDPE microplastics: a mesocosm experiment. Environ Pollut. 2019;245:829-35. https://doi. org/10.1016/j.envpol.2018.11.044.

178. M Yu M Ploeg van der E Huerta Lwanga X Yang S Zhang X Ma CJ Ritsema V Geissen 2019 Leaching of microplastics by preferential flow in earthworm (Lumbricus terrestris) burrows Environ Chem https://doi. org/10.1071/EN18161

179. Yu M, van der Ploeg M, Ma X, Ritsema CJ, Geissen V. Effects of microplastics and earthworm burrows on soil macropore water flow within a laboratory soil column setup. Vadose Zone J. 2020;19(1): e20059. https://doi.org/10.1002/vzj2.20059.

180. L Yu J Zhang Y Liu L Chen S Tao W Liu 2021 Distribution characteristics of microplastics in agricultural soils from the largest vegetable production base in China Sci Total Environ https://doi.org/10.1016/j.scitotenv. 2020.143860

181. S Zhang X Liu X Hao J Wang Y Zhang 2020 Distribution of low-density microplastics in the mollisol farmlands of northeast China Sci Total Environ https://doi.org/10.1016/j.scitotenv.2019.135091

182. Zhang L, Sintim HY, Bary Al, Hayes DG, Wadsworth LC, Anunciado MB, Flury M. Interaction of Lumbricus terrestris with macroscopic polyethylene and biodegradable plastic mulch. Sci Total Environ. 2018;635:16008. https://doi.org/10.1016/j.scitotenv.2018.04.054.

183. L Zhang Y Xie J Liu S Zhong Y Qian P Gao 2020 An overlooked entry pathway of microplastics into agricultural soils from application of sludge-based fertilizers Environ Science Tech https://doi.org/10.1021/ acs.est.9b07905

184. GS Zhang FX Zhang XT Li 2019 Effects of polyester microfibers on soi physical properties: perception from a field and a pot experiment Sci Total Environ https://doi.org/10.1016/j.scitotenv.2019.03.149

185. B Zhou J Wang H Zhang H Shi Y Fei S Huang Y Tong D Wen Y Luo D Barceló 2020 Microplastics in agricultural soils on the coastal plain of Hangzhou Bay, east China: multiple sources other than plastic mulching film J Hazard Mater https://doi.org/10.1016/j.jhazmat.2019.121814

186. J Zhu C Wang 2020 Biodegradable plastics: green hope or greenwashing? Mar Pollut Bull https://doi.org/10.1016/j.marpolbul.2020.111774

187. S Ziajahromi PA Neale L Rintoui FDL Leusch 2017 Wastewater treatment plants as a pathway for microplastics: development of a new approach to sample wastewater-based microplastics Water Res https://doi.org/ 10.1016/j.watres.2017.01.042

188. KA Zubris BK Richards 2005 Synthetic fibers as an indicator of land application of sludge Environ Pollut https://doi.org/10.1016/j.envpol. 2005.04.013

189. ER Zylstra 2013 Accumulation of wind-dispersed trash in desert environments J Arid Environ https://doi.org/10.1016/j.jaridenv.2012.10.004

\section{Publisher's Note}

Springer Nature remains neutral with regard to jurisdictional claims in published maps and institutional affiliations.

\section{Submit your manuscript to a SpringerOpen ${ }^{\circ}$ journal and benefit from:}

- Convenient online submission

- Rigorous peer review

- Open access: articles freely available online

- High visibility within the field

- Retaining the copyright to your article

Submit your next manuscript at $\boldsymbol{\nabla}$ springeropen.com 